\title{
Merged SAGE II, Ozone_cci and OMPS ozone profile dataset and evaluation of ozone trends in the stratosphere
}

\author{
Viktoria F. Sofieva ${ }^{1}$, Erkki Kyrölä ${ }^{1}$, Marko Laine ${ }^{1}$, Johanna Tamminen ${ }^{1}$, Doug Degenstein ${ }^{2}$, Adam Bourassa ${ }^{2}$, \\ Chris Roth $^{2}$, Daniel Zawada ${ }^{2}$, Mark Weber ${ }^{3}$, Alexei Rozanov ${ }^{3}$, Nabiz Rahpoe $^{3}$, Gabriele Stiller $^{4}$, Alexandra Laeng $^{4}$, \\ Thomas von Clarmann ${ }^{4}$, Kaley A. Walker ${ }^{5}$, Patrick Sheese ${ }^{5}$, Daan Hubert ${ }^{6}$, Michel van Roozendael ${ }^{6}$, Claus Zehner ${ }^{7}$, \\ Robert Damadeo $^{8}$, Joseph Zawodny ${ }^{8}$, Natalya Kramarova ${ }^{9}, 10$, and Pawan K. Bhartia ${ }^{9}$ \\ ${ }^{1}$ Finnish Meteorological Institute, Helsinki, Finland \\ ${ }^{2}$ Institute of Space and Atmospheric Studies, University of Saskatchewan, Saskatoon, Canada \\ ${ }^{3}$ Institute for Environmental Physics, University of Bremen, Bremen, Germany \\ ${ }^{4}$ Karlsruhe Institute of Technology, Institute of Meteorology and Climate Research, Karlsruhe, Germany \\ ${ }^{5}$ Department of Physics, University of Toronto, Toronto, Canada \\ ${ }^{6}$ Royal Belgian Institute for Space Aeronomy (BIRA-IASB), Brussels, Belgium \\ ${ }^{7}$ ESA/ESRIN, Frascati, Italy \\ ${ }^{8}$ NASA Langley Research Center, Hampton, VA, USA \\ ${ }^{9}$ NASA Goddard Space Flight Center, Silver Spring, MD, USA \\ ${ }^{10}$ Science Systems and Applications Inc., Lanham, MD, USA
}

Correspondence to: Viktoria F. Sofieva (viktoria.sofieva@ fmi.fi)

Received: 28 June 2017 - Discussion started: 3 July 2017

Revised: 31 August 2017 - Accepted: 10 September 2017 - Published: 23 October 2017

\begin{abstract}
In this paper, we present a merged dataset of ozone profiles from several satellite instruments: SAGE II on ERBS, GOMOS, SCIAMACHY and MIPAS on Envisat, OSIRIS on Odin, ACE-FTS on SCISAT, and OMPS on Suomi-NPP. The merged dataset is created in the framework of the European Space Agency Climate Change Initiative (Ozone_cci) with the aim of analyzing stratospheric ozone trends. For the merged dataset, we used the latest versions of the original ozone datasets. The datasets from the individual instruments have been extensively validated and intercompared; only those datasets which are in good agreement, and do not exhibit significant drifts with respect to collocated ground-based observations and with respect to each other, are used for merging. The long-term SAGE-CCI-OMPS dataset is created by computation and merging of deseasonalized anomalies from individual instruments.

The merged SAGE-CCI-OMPS dataset consists of deseasonalized anomalies of ozone in $10^{\circ}$ latitude bands from $90^{\circ} \mathrm{S}$ to $90^{\circ} \mathrm{N}$ and from 10 to $50 \mathrm{~km}$ in steps of $1 \mathrm{~km}$ covering the period from October 1984 to July 2016. This newly created dataset is used for evaluating ozone trends in the strato-
\end{abstract}

sphere through multiple linear regression. Negative ozone trends in the upper stratosphere are observed before 1997 and positive trends are found after 1997. The upper stratospheric trends are statistically significant at midlatitudes and indicate ozone recovery, as expected from the decrease of stratospheric halogens that started in the middle of the 1990s and stratospheric cooling.

\section{Introduction}

The ozone layer protects life on Earth from harmful ultraviolet solar radiation and plays an important role in the radiation budget of the atmosphere. Its evolution is intimately coupled to climate change. Starting in the 1970s, the stratospheric ozone declined worldwide, with the largest decline of 4 to $8 \%$ decade $^{-1}$ seen in the upper stratosphere (WMO, 2014; Steinbrecht et al., 2017, and references therein). After international agreements on the reduction of ozone-depleting substances (Montreal Protocol and its Amendments), the first signatures of ozone recovery were observed, at least in cer- 
tain latitude and altitude regions (e.g., Newchurch et al., 2003; Kyrölä et al., 2013; Bourassa et al., 2014; Eckert et al., 2014; Harris et al., 2015; Tummon et al., 2015; WMO, 2014). About half of the recent increase in upper stratospheric ozone is attributed to climate change (WMO, 2014). As ozone recovery will remain strongly influenced by climate change, continued monitoring of stratospheric ozone and its vertical structure is important.

The European Space Agency (ESA) Ozone Climate Change Initiative (Ozone_cci) aims to generate new highquality satellite datasets that are essential to assess the fate of atmospheric ozone and better understand its link with anthropogenic activities (http://www.esa-ozone-cci.org). Participating in the Ozone_cci project are three instruments on board Envisat, GOMOS (Global Ozone Monitoring by Occultation of Stars), MIPAS (Michelson Interferometer for Passive Atmospheric Sounding) and SCIAMACHY (SCanning Imaging Spectrometer for Atmospheric CHartographY), as well as OSIRIS (Optical Spectrograph and InfraRed Imaging System) and SMR (Sub-Millimeter Radiometer), both aboard Odin, and ACE-FTS (Atmospheric Chemistry Experiment Fourier Transform Spectrometer) on SCISAT.

Satellite data provide good spatial coverage, but the temporal coverage of their data records is usually too short for trend analyses. For reliable estimates of ozone trends, long-term data records are needed in order to separate natural ozone variability (e.g., due to solar activity) and longterm trends. For the assessment of ozone trends, several merged ozone datasets with a good vertical resolution have been created (Harris et al., 2015; Tummon et al., 2015): GOZCARDS (Froidevaux et al., 2015), SWOOSH (Davis et al., 2016), SAGE II-OSIRIS (Bourassa et al., 2014) and SAGE II-GOMOS (Kyrölä et al., 2013). In construction of these datasets, different merging approaches are used. GOZCARDS and SWOOSH provide ozone mixing ratios on pressure levels, while SAGE II-OSIRIS and SAGE II-GOMOS datasets provide number density on a geometric altitude grid as used in the respective data retrievals.

This paper introduces a new dataset in which reliable satellite data providing ozone profiles on an altitude grid are merged into a climate data record for assessment of ozone trends. These are from the five Ozone_cci instruments, GOMOS, MIPAS, SCIAMACHY, OSIRIS and ACE-FTS, covering the period 2001-2016, which are merged with the data from SAGE II (Stratospheric Aerosol and Gases Experiment II, 1984-2005) and OMPS-LP (Ozone Monitor Profiling Suite-Limb Profiler, 2012-2016). Since the last ozone assessment (WMO, 2014), the Ozone_cci satellite data were processed with new retrieval versions. The stability of the individual instrument data records has been extensively studied; only sufficiently stable data are used for the merged dataset. The merging is performed on deseasonalized anomalies computed from each individual dataset. This method is often used for creating long-term data records (e.g., IPCC, 2013; WMO, 2014), as well as for trend analyses of ozone (e.g., Bourassa et al., 2014; Randel and Thompson, 2011; Sioris et al., 2014; Steinbrecht et al., 2017), stratospheric temperature (Randel et al., 2009; Seidel et al., 2011; Thompson et al., 2012) and water vapor (Jones et al., 2009). The main advantage of using deseasonalized anomalies is that biases due to different sampling patterns (including the difference in local time) and instrumental biases are automatically removed, if the sampling patterns do not change over time. While assessing the trends using deseasonalized anomalies, there is no need to fit the seasonal variations with harmonic functions (the seasonal variations do not necessarily allow a simple expansion into a few harmonics).

The paper is organized as follows. Section 2 describes the ozone datasets from the individual instruments. Section 3 is dedicated to comparisons of the individual datasets and evaluation of the deseasonalized anomalies. In Sect. 4 we describe the merging method and associated uncertainties. Section 5 is dedicated to evaluation of ozone trends in the stratosphere using the merged SAGE-CCI-OMPS dataset. The information about data availability is provided in Sect. 6 and the conclusions are summarized in Sect. 7.

\section{Data}

Ozone measurements available from different satellite instruments cover all seasons and various times of day and also have good latitudinal coverage. The information about individual datasets is collected in Table 1. All of the data used for creating the merged dataset have a sufficiently good vertical resolution of $1-3 \mathrm{~km}$ in the stratosphere and in the UTLS (upper troposphere and the lower stratosphere). For all instruments used here, ozone profiles are retrieved on the geometric altitude grid. The majority of the datasets SAGE II, GOMOS, OSIRIS, SCIAMACHY and OMPS provide number density ozone profiles; therefore this representation is adopted for the merged dataset. For ACE-FTS and MIPAS, the retrievals are in volume mixing ratio on an altitude grid. Conversion to number density profiles is performed using temperature profiles retrieved by these instruments, thus providing consistent (i.e., without using external information about temperature and pressure profiles) representation of number density ozone profiles. Since the publication of the WMO 2014 ozone assessment, new processing versions of the Ozone_cci datasets were introduced. Generally, the newly reprocessed ozone datasets have smaller biases and are more stable (further details are provided in the descriptions of individual datasets below).

The time series of the number of available ozone profiles per month from each instrument is shown in Fig. 1. Note that for some instruments, the selected time period is shorter than the full operation period (Table 1). The individual datasets have been compared with each other and with ground-based data and only time periods when the instruments were op- 
Table 1. Information about the datasets used in the merged dataset.

\begin{tabular}{|c|c|c|c|c|c|c|}
\hline Instrument/satellite & $\begin{array}{l}\text { Processor, } \\
\text { data source }\end{array}$ & Time period & Local time & $\begin{array}{l}\text { Vertical } \\
\text { resolution }\end{array}$ & $\begin{array}{l}\text { Estimated } \\
\text { precision }\end{array}$ & $\begin{array}{l}\text { Profiles } \\
\text { per day }\end{array}$ \\
\hline SAGE II/ERBS & $\begin{array}{l}\text { NASA v7.0, } \\
\text { original files }\end{array}$ & Oct 1984-Aug 2005 & sunrise, sunset & $\sim 1 \mathrm{~km}$ & $0.5-5 \%$ & $14-30$ \\
\hline OSIRIS/Odin & $\begin{array}{l}\text { USask v5.10, } \\
\text { HARMOZ_ALT }\end{array}$ & Nov 2011-Jul 2016 & $06: 00,18: 00$ & $2-3 \mathrm{~km}$ & $2-10 \%$ & $\sim 250$ \\
\hline GOMOS/Envisat & $\begin{array}{l}\text { ALGOM2s v1.0, } \\
\text { HARMOZ_ALT }\end{array}$ & Aug 2002-Aug 2011 & $22: 00$ & $2-3 \mathrm{~km}$ & $0.5-5 \%$ & $\sim 110$ \\
\hline MIPAS/Envisat & $\begin{array}{l}\text { KIT/IAA } \\
\text { v7R_O3_240, } \\
\text { HARMOZ_ALT }\end{array}$ & Jan 2005-Apr 2012 & $22: 00,10: 00$ & $3-5 \mathrm{~km}$ & $1-4 \%$ & $\sim 1000$ \\
\hline SCIAMACHY/Envisat & $\begin{array}{l}\text { UBr v3.5, } \\
\text { HARMOZ_ALT }\end{array}$ & Aug 2003-Apr 2012 & $10: 00$ & $3-4 \mathrm{~km}$ & $1-7 \%$ & $\sim 1300$ \\
\hline ACE-FTS/SCISAT & $\begin{array}{l}\text { v3.5/3.6, } \\
\text { HARMOZ_ALT }\end{array}$ & Feb 2004-Dec 2016 & sunrise, sunset & $\sim 3 \mathrm{~km}$ & $1-3 \%$ & $14-30$ \\
\hline OMPS/Suomi NPP & $\begin{array}{l}\text { USask 2-D v1.0.2, } \\
\text { HARMOZ_ALT }\end{array}$ & Apr 2012-Aug 2016 & $13: 30$ & $\sim 1 \mathrm{~km}$ & $2-10 \%$ & $\sim 1600$ \\
\hline
\end{tabular}

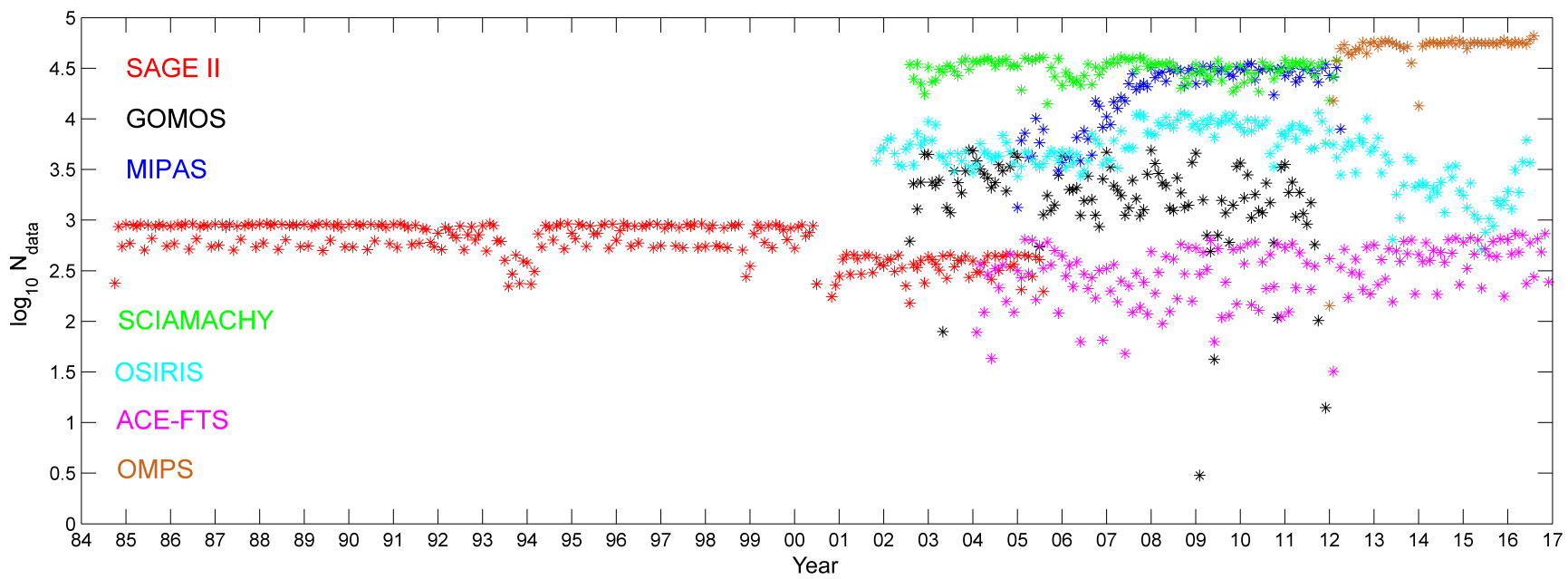

Figure 1. Monthly data volume (logarithm of number of measurements).

erating optimally are selected for merging (details are given later in Sect. 3).

The Ozone_cci datasets, which are used for merging, are included in the user-friendly HARMonized dataset of OZone profiles (HARMOZ) (Sofieva et al., 2013) and are available at the Ozone_cci web-page (http://www.esa-ozone-cci.org/ $? q=$ node/160). HARMOZ consists of the original retrieved ozone profiles from each instrument, which are screened for invalid data by the instrument experts and are presented on a vertical grid and in a common netCDF4 format, which simplifies the data usage. Below are more detailed descriptions of the individual datasets.

\subsection{SAGE II}

SAGE II operated on board the Earth Radiation Budget Satellite (ERBS) from 1984 to 2005 . Using the solar occultation technique to observe the Sun during sunrises and sunsets, SAGE II observed the atmosphere in seven channels with wavelengths between 375 and $1030 \mathrm{~nm}$ (Mauldin III et al., 1985). Vertical slant-path transmission profiles with a $1 \mathrm{~km}$ resolution were inverted into profiles of ozone, aerosol extinction, water vapor and nitrogen dioxide using a simple "onion-peeling" method (Chu et al., 1989). Ozone is inferred primarily from spectral measurements near $600 \mathrm{~nm}$ at the peak of the Chappuis band, and the resulting highquality profiles have random uncertainty $<1 \%$ in the stratosphere (McCormick et al., 1989). This work uses version 7.00 of the SAGE II dataset (Damadeo et al., 2013) which 
has been filtered for invalid values as described in Damadeo et al. (2014). The data corresponding to heavy aerosol loading are excluded as recommended by Wang et al. (2002).

Due to the self-calibrating nature of occultation measurements, SAGE II data are stable (Hubert et al., 2016) and have been thoroughly validated (e.g., Damadeo et al., 2013; McCormick et al., 1989; Wang et al., 2002) and used in previous ozone assessments (e.g., WMO, 2011). Given their quality and stability, SAGE II data are also included in several merged datasets that have been used in the most recent ozone assessment (WMO, 2014). Since SAGE II offers one of only a few datasets during the 1990s or earlier, it is often the only source of data prior to about 2002 incorporated into many merged datasets.

\subsection{GOMOS}

GOMOS is a stellar occultation instrument that operated on board Envisat in 2002-2012 (Bertaux et al., 2010; Kyrölä et al., 2010). Ozone profiles are retrieved from the ultraviolet (UV) and visible spectrometer measurements at wavelengths between 250 and $692 \mathrm{~nm}$. The main dataset consists of nighttime ozone profiles (with solar zenith angle larger than $105^{\circ}$ ), which are retrieved from atmospheric transmittance spectra. There also exists the bright-limb ozone profile dataset derived from the GOMOS limb scattering measurements (Tukiainen et al., 2011, 2015). However, the altitude range for the bright-limb ozone profiles is limited, and there are some indications of a drift of retrieved ozone concentrations. Therefore, only nighttime GOMOS ozone profiles are used for the merged dataset. The GOMOS ozone profiles are obtained with the ALGOM2s v1.0 processor (Sofieva et al., 2017). ALGOM2s is nearly identical to the ESA IPF v6 processor (GOMOS IPF v6 data were used in the WMO-2014 ozone assessment) in the stratosphere, but has improved data quality in the UTLS.

GOMOS provides stratospheric ozone profiles with a vertical resolution of $2 \mathrm{~km}$ below 30 and $3 \mathrm{~km}$ above $30 \mathrm{~km}$, with a linear transition between (Tamminen et al., 2010). The vertical resolution of the GOMOS ozone profiles is the same for all occultations due to the Tikhonov-type (Tikhonov, 1963) target-resolution regularization (Kyrölä et al., 2010; Sofieva et al., 2004). The stellar flux recorded by GOMOS, and thus signal-to-noise ratio and precision of retrieved profiles, depends on stellar magnitude and spectral class. The estimated random uncertainty of GOMOS ozone profiles in the stratosphere is $0.5-5 \%$ (Tamminen et al., 2010). Validation of estimated uncertainties for ozone profiles in the stratosphere has shown that they are realistic except for cases when ozone profiles are derived from occultations of dim stars (Sofieva et al., 2014b).

The validation and intercomparison results have shown that the GOMOS nighttime ozone profiles have small biases with respect to ground-based measurements (Hubert et al., 2016). GOMOS profiles are in very good agreement with SAGE II and OSIRIS measurements in the stratosphere (Adams et al., 2014; Hubert et al., 2016; Kyrölä et al., 2013), as well as with OSIRIS, MIPAS and ACE-FTS measurements in the UTLS (Sofieva et al., 2017).

The GOMOS exploits a self-calibrating measurement principle, and therefore a high stability of the GOMOS data is expected (Kyrölä et al., 2010). It turned out that it is important to exclude the ozone data from the stars with insufficient UV flux. These data are biased and can induce artificial data drifts. GOMOS IPF V6 data have been combined into the merged SAGE II-GOMOS dataset, which was used for ozone trend analysis (Harris et al., 2015; Kyrölä et al., 2013; Laine et al., 2014; Tummon et al., 2015; WMO, 2014). The new GOMOS ALGOM2s dataset used for the merged dataset has not only improved data quality in the UTLS, but it is also expected to be more stable in the whole atmosphere due to an advanced screening of unreliable data (Sofieva et al., 2017).

\subsection{MIPAS}

The Michelson Interferometer for Passive Atmospheric Sounding is an infrared limb emission spectrometer that was flown on the Envisat platform (Fischer et al., 2008). In 20022004 , the instrument operated at full spectral resolution. Due to a failure of the instrument's mirror slide in 2004, the operations were suspended for almost a year and were resumed in 2005 with reduced spectral, but improved vertical, resolution. These operations continued until the loss of communications with the ENVISAT platform in April 2012.

Stratospheric ozone profiles are retrieved from MIPASENVISAT limb emission spectra. In this work, we use the scientific MIPAS processor V7R_O3_240 developed at Karlsruhe Institute of Technology, IMK/IAA V7R_O3_240. The retrieval is performed via constrained inverse modeling of limb radiances. In the stratospheric and tropospheric retrievals, local thermodynamic equilibrium (LTE) is assumed. A detailed description can be found in von Clarmann et al. $(2003,2009)$. The data version used in this work is retrieved from new level-1 spectra (version V7), in which a new set of (time-dependent) correction coefficients for the nonlinearity in the detectors' response functions is implemented. This has a major positive impact on the stability of the dataset (Laeng et al., 2017). The main updates in the retrieval strategy include the following. The retrieval of temperature, which is crucial for subsequent trace-gas retrievals, has been revised. The atmospheric background continuum radiation is no longer set to zero above $30 \mathrm{~km}$ but fitted also for higher altitudes. The treatment of interfering $\mathrm{H}_{2} \mathrm{O}$ lines has been improved, and two additional microwindows are used (see Laeng et al., 2017, for details).

Due to their different data characteristics, the two MIPAS measurement periods are usually treated as two independent datasets. Their processing schemes are different, and the vertical resolution of the early MIPAS period is lower than that of the later period: $3.5-6 \mathrm{~km}$ vs. $2-5 \mathrm{~km}$ for retrieved ozone. 
The vertical resolution of the MIPAS early period is also worse than the vertical resolution of all of the other datasets used in the merged dataset. Instead of downgrading the vertical resolution of all other participating datasets to that of the MIPAS early period, which is also very short, the MIPAS early period data were discarded from the merging. The mean uncertainty of retrieved MIPAS ozone profiles in 2005-2012 is $0.05-0.1 \mathrm{ppmv}(1-5 \%)$.

\subsection{SCIAMACHY}

SCIAMACHY, aboard ENVISAT, was a European spaceborne spectrometer measuring the upwelling radiation from the Earth's atmosphere in the UV, visible, near-infrared and shortwave-infrared spectral ranges. The instrument provided measurements in nadir, limb, and solar or lunar occultation viewing geometries. In the limb viewing geometry, the SCIAMACHY instrument scanned the Earth's atmosphere vertically from about $3 \mathrm{~km}$ below the horizon ( $0 \mathrm{~km}$ after October 2010) with a vertical sampling of about $3.3 \mathrm{~km}$ and a vertical instantaneous field of view of $2.6 \mathrm{~km}$ (at tangent height). At each tangent height, a horizontal scan within a total swath of $960 \mathrm{~km}$ was performed. A detailed description of the instrument and its measurement modes is given by Burrows et al. (1995) and Bovensmann et al. (1999).

This study uses V3.5 of the SCIAMACHY limb ozone retrieval, which is a completely new retrieval compared to V2.9 used by, for example, Sofieva et al. (2013). The V3.5 SCIAMACHY retrieval uses six spectral windows (264-265, 266.5-267.7, 272.5-273.8, 276.5-278, 282.5284, 289-309.5 nm) in the Hartley ozone absorption band as well as one window $(325-331 \mathrm{~nm})$ in the Huggins band and one window (495-576 nm) in the Chappuis ozone band. The radiances in the Huggins and Chappuis absorption bands are sun-normalized while normalization to an upper tangent height is used in the Hartley absorption band. To reduce the influence of calibration errors and broad-band spectral features, a polynomial is subtracted from the logarithms of the normalized radiances in all spectral windows except for the first three. The zero-order polynomial (i.e. a constant) is subtracted from the measurements in the last three windows in the Hartley band (a common polynomial is calculated for the fourth and fifth spectral windows), while a linear and a quadratic polynomials are subtracted in the Huggins and Chappuis bands, respectively. Independent values for the surface albedo in the UV and visible spectral ranges are retrieved simultaneously with the ozone number density.

Ozone is retrieved from 8 to $60 \mathrm{~km}$ on the measurement tangent height grid. Tangent heights with clouds and/or highly increased aerosols in the field of view are rejected and the ECSTRA (Extinction Coefficient for STRatospheric Aerosol) database (Bingen and Fussen, 2000; Fussen and Bingen, 1999) is used as the aerosol model (based on SAGE II climatology). The random error for V3.5 ozone retrievals is on the order of $1-5 \%$, lower than that reported in Rahpoe et al. (2013) for an earlier version. The pointing accuracy is similar to previous versions (see Sofieva et al., 2013). The vertical resolution of the SCIAMACHY profiles is about $3.3 \mathrm{~km}$. Intercomparison of V3.5 SCIAMACHY limb ozone with microwave limb sounder (MLS) and ozonesonde data shows agreement generally within 5\% (paper in preparation).

\subsection{OSIRIS}

OSIRIS (Optical Spectrograph and InfraRed Imaging System) is a Canadian instrument on board the Swedish satellite Odin that was launched in February of 2001. It is a limbviewing device that makes repeated measurements of the limb scattered radiance in the UV and visible spectral ranges with a sampling of approximately $2 \mathrm{~km}$ between 10 and $100 \mathrm{~km}$ of altitude. OSIRIS uses limb radiance spectra to generate ozone profiles in a range from $80^{\circ} \mathrm{S}$ to $80^{\circ} \mathrm{N}$. Concentrations are retrieved on a $1 \mathrm{~km}$ grid from 10.5 to $59.5 \mathrm{~km}$ and have a vertical resolution of $\sim 2 \mathrm{~km}$. The ozone retrieval by the University of Saskatchewan uses a multiplicative algebraic reconstruction technique, as described in Degenstein et al. (2009). The OSIRIS instrument is still operational with no degradation in data quality.

Bourassa et al. (2014) merged SAGE II and OSIRIS data to examine trends in stratospheric ozone. Part of the apparent trends they showed in OSIRIS ozone has since been attributed to a time-dependent altitude registration offset and has been corrected with a robust technique that uses stable features in the Rayleigh scattered limb radiance profile (e.g., Moy et al., 2017). The drift-corrected radiances have been used to process OSIRIS version 5.10 ozone. The v5.10 retrieval scheme is identical to that of version 5.07 and analysis of the improved OSIRIS data record results in reduced ozone recovery trends in the upper stratosphere (Bourassa et al., 2017). Comparisons of trends derived with OSIRIS version 5.10 with OMPS USask 2-D v1.0.2 (Zawada et al., 2017) ozone data records reveal the drift contained in OSIRIS version 5.07 has been mitigated.

\subsection{OMPS-LP}

The Ozone Mapping and Profiler Suite Limb Profiler (OMPS-LP) on board the Suomi-NPP satellite has been taking measurements of limb-scattered sunlight from early 2012 to present (Flynn et al., 2006). OMPS-LP images the atmosphere using three vertical slits, one aligned with the orbital plane and the others separated by $250 \mathrm{~km}$ at the tangent point on either side of the orbital track. Imaging allows OMPS-LP to obtain along track and vertical sampling of approximately 125 and $1 \mathrm{~km}$, respectively. Spectral information in the range $270-1000 \mathrm{~nm}$ is obtained by employing a prism spectrometer.

For HARMOZ, the OMPS-LP ozone data processed in the University of Saskatchewan are used (Zawada et al., 2017). 
Hereafter, we refer OMPS-LP to as OMPS for short, and the processor as USask 2-D v1.0.2. The USask 2-D retrieval accounts for atmospheric variations along the orbital track by using the SASKTRAN-HR forward model (Zawada et al., 2015) and simultaneously retrieving the ozone field for an entire orbit, rather than processing each vertical image separately. Only data from the center slit of OMPS is used, as the other two slits are not aligned with the orbital track. Profiles are retrieved with a vertical resolution of $1-2 \mathrm{~km}$ and an along-track resolution of $300-400 \mathrm{~km}$. Individual profiles have a mean uncertainty of $4-6 \%$ for most of the upper and middle stratosphere, with values increasing to approximately $30 \%$ just below the tropopause.

\subsection{ACE-FTS}

ACE-FTS is an instrument on board the Canadian satellite SCISAT (Bernath et al., 2005; Bernath, 2017). It was launched in August 2003, and data are available from February 2004 to present. It provides latitudinal coverage from about $85^{\circ} \mathrm{N}$ to $85^{\circ} \mathrm{S}$ with complete coverage every 3 months. The ACE-FTS is a high-spectral-resolution $\left(0.02 \mathrm{~cm}^{-1}\right)$ Fourier transform spectrometer measuring from 2.2 to $13 \mu \mathrm{m}$ (750-4400 $\mathrm{cm}^{-1}$ ) (Bernath et al., 2005). Operating in solar occultation mode, ACE-FTS provides detailed profiles of the Earth's atmosphere for more than 30 chemical species.

The ACE-FTS processor employs a nonlinear leastsquares global-fit approach to retrieve volume mixing ratio profiles from spectra measured for each occultation using spectra simulated by a forward model. This processor is described in Boone et al. (2005). The current versions of the ACE-FTS dataset used for HARMOZ are v3.5/3.6, as described in Boone et al. (2013). The only difference between v3.5 (typically 2004-February 2013) and v3.6 (March 2013present and $\sim 5 \%$ of 2004-February 2013 data) is the computer system used to perform the retrieval. A local computer was used for v3.5 and a shared supercomputing system is used for v3.6. For the ozone retrieval, 33 microwindows are used covering the range from 1027 to $1169 \mathrm{~cm}^{-1}$ with seven additional windows at 829, 923, 1105, 2149 and $2673 \mathrm{~cm}^{-1}$ to better account for interfering species CFC-12, HCFC-22, $\mathrm{CFC}-11, \mathrm{~N}_{2} \mathrm{O}, \mathrm{CH}_{4}, \mathrm{HCOOH}, \mathrm{CO}_{2}$, and their isotopologues. The altitude range of the retrieved ozone profiles is from cloud tops $(\sim 5 \mathrm{~km})$ to $95 \mathrm{~km}$ and the vertical resolution is $\sim 3-4 \mathrm{~km}$ (based on the field-of-view of the ACE-FTS instrument) (Boone et al., 2005).

Data quality flags are provided with the ACE-FTS dataset (Sheese et al., 2015). For HARMOZ, data at altitudes where there was a flag value greater than 0 and data for all profiles with flag values of 4-6 were excluded (version 2.0 of the ACE-FTS v3.5/3.6 quality flags). In a recent validation study comparing ACE-FTS ozone to MLS and MIPAS profiles over the period 2004-2012, the average systematic bias was found to be $+2 \%$ between 10 and $45 \mathrm{~km}$ and $0-+19 \%$ above $46 \mathrm{~km}$ (Sheese et al., 2017).

\section{Preparation and selection of data for merging}

For creating monthly zonal mean data from the individual instruments, $10^{\circ}$ latitude bands from $90^{\circ} \mathrm{S}$ to $90^{\circ} \mathrm{N}$ are used. For all sensors, the monthly zonal average is computed as the mean of ozone profiles $x_{k}(z)$ :

$\rho(z)=\frac{1}{N} \sum x_{k}(z)$

where $N$ is the number of measurements $(N>10)$. The uncertainty of the monthly mean $\sigma_{\rho}^{2}$ can be estimated as the standard error of the mean:

$\sigma_{\rho}^{2}=\frac{s^{2}}{N}$,

where $s^{2}=\left\langle\left(x_{k}-\rho\right)^{2}\right\rangle$ is the sample variance. Equation (2) is valid for random samples of uncorrelated data. As shown by Toohey and von Clarmann (2013), some deviations of the real standard error of the mean from that calculated using Eq. (2) can be observed for satellite observations. In our study, Eq. (2) is used as an approximate estimate of the standard error of the mean, since no estimates considering the impact of the correlations caused by the orbital sampling are currently available. In Eq. (2), we used a robust estimator for the sample variance: $s=0.5 \cdot\left(P_{84}-P_{16}\right)$, where $P_{84}$ and $P_{16}$ are the 84th and 16th percentiles of the distribution, respectively. Monthly zonal mean, sample variability $s$ and standard error of the mean from 15 to $50 \mathrm{~km}$ altitude in January 2008 are shown for the Ozone_cci instruments in Fig. 2. The ozone distributions shown in Fig. 2 are very similar for all datasets. Due to the large number of data available for averaging, the standard error of the mean is usually less than $1 \%$ in the stratosphere.

Satellite measurements sample a continuous ozone field at some locations and times. To characterize the nonuniformity of sampling, we computed inhomogeneity measures in latitude, $H_{\text {lat }}$, and in time, $H_{\text {time }}$ (Sofieva et al., 2014a). Each inhomogeneity measure $H$ is the linear combination of two classical inhomogeneity measures, asymmetry $A$ and entropy $E$ (for definition of these parameters, see Sofieva et al., 2014a):

$H=\frac{1}{2}(A+(1-E))$.

The inhomogeneity measure $H$ ranges from 0 to 1 (the more homogeneous, the smaller $H$ ). For dense samplers (MIPAS, SCIAMACHY, OMPS), the inhomogeneity is close to zero for nearly all latitude bins. For other instruments, the inhomogeneity measure can be large for some latitude-time bins. The monthly zonal mean data with very high inhomogeneity are excluded from data merging (see below). The monthly zonal mean data from the individual instruments are available at the Ozone_cci web-page (www.esa-ozone-cci.org). 
(a)
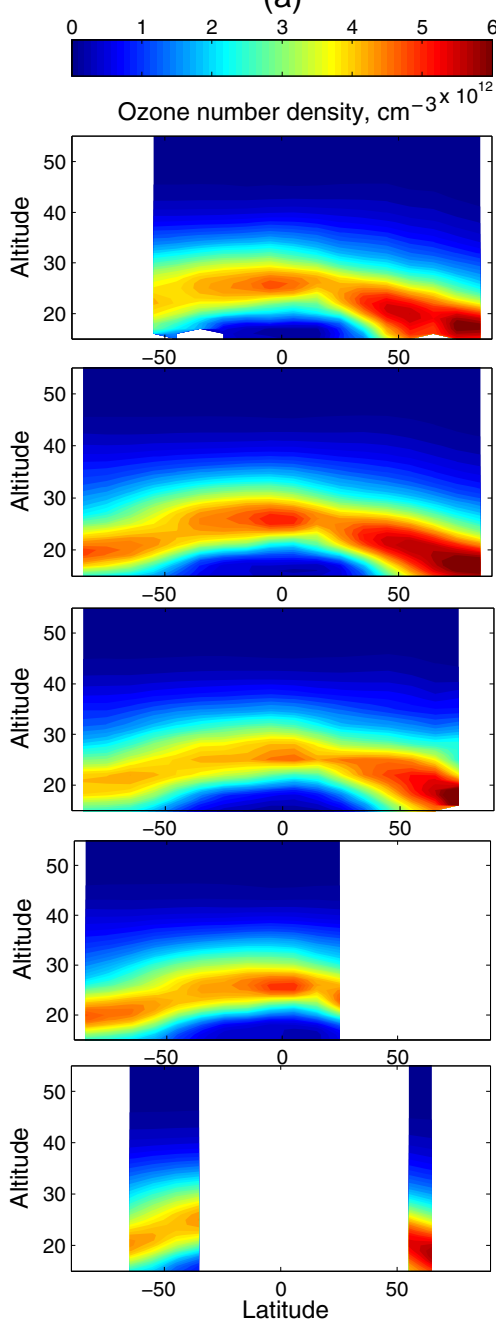

(b)
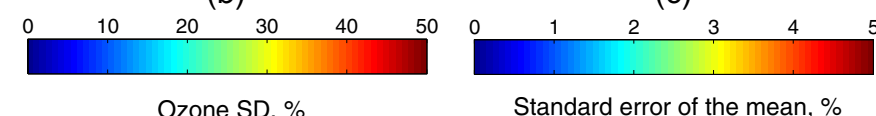

Standard error of the mean, \%
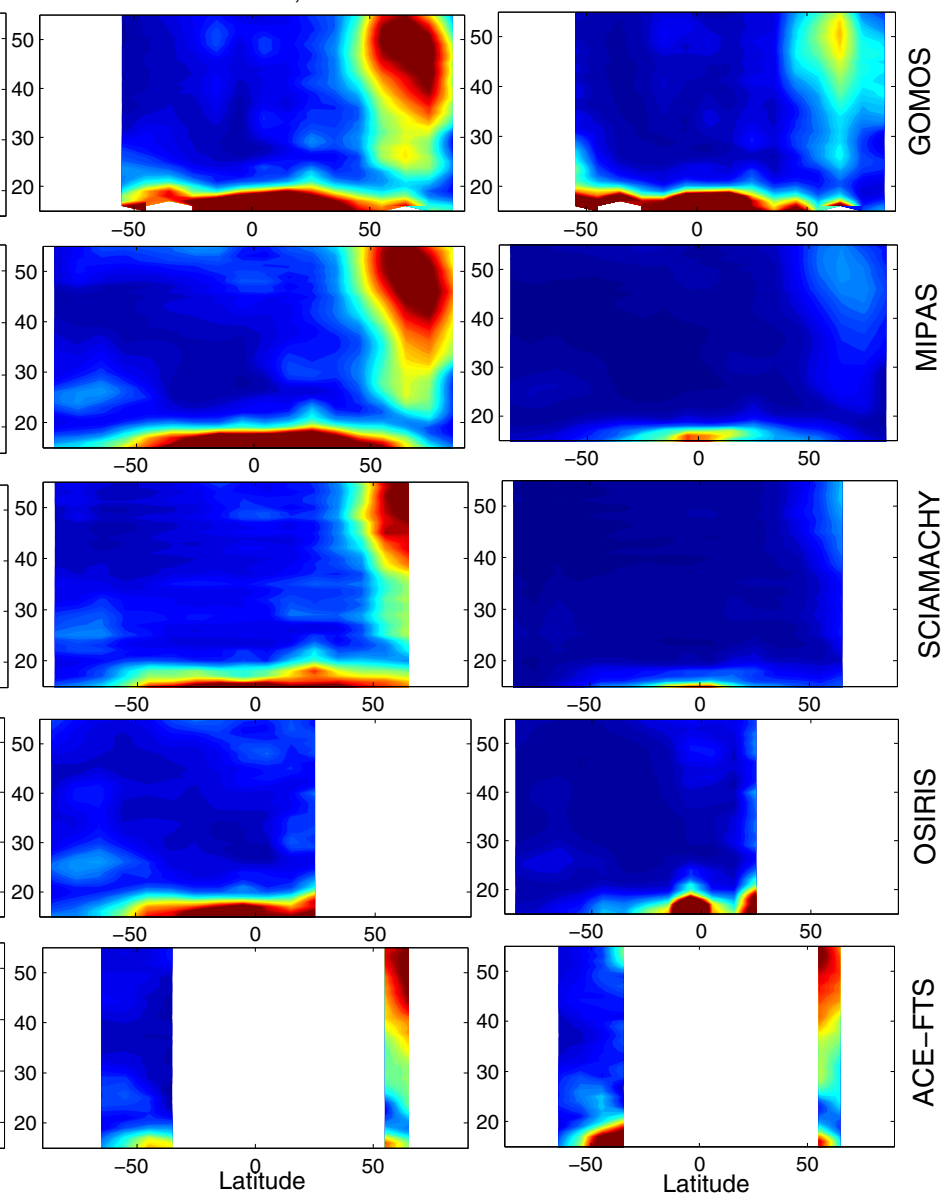

Figure 2. (a) Monthly zonal mean ozone profiles for January 2008 for Ozone_cci instruments, (b) sample variability (\%), (c) standard error of the mean calculated using Eq. (2).

For each instrument, latitude band and altitude level, the deseasonalized anomalies are computed as follows:

$$
\Delta\left(t_{i}\right)=\frac{\rho\left(t_{i}\right)-\rho_{\mathrm{m}}}{\rho_{\mathrm{m}}},
$$

where $\rho\left(t_{i}\right)$ is the monthly mean value at a certain altitude and latitude band corresponding to time $t_{i}$ and $\rho_{\mathrm{m}}$ is the mean value for the corresponding month $m$, i.e. $\rho_{\mathrm{m}}=\frac{1}{N_{\mathrm{m}}} \sum_{j=1}^{N_{\mathrm{m}}} \rho_{j}$, $N_{\mathrm{m}}$ being the number of monthly mean values $\rho_{j}$ in a given month $m$ available from all years.

For the Ozone_cci instruments, the seasonal cycle is evaluated using the overlapping period 2005-2011. The seasonal cycle for SAGE II is computed using years 1985-2004 and for OMPS using the years 2012-2016. In computation of deseasonalized anomalies, we ignored data from those latitudetime bins with the mean inhomogeneity $H_{\text {tot }}=0.5\left(H_{\text {lat }}+\right.$
$\left.H_{\text {time }}\right)>0.8$ (for all considered satellite instruments, longitudinal inhomogeneity is negligible, Sofieva et al., 2014a).

Figure 3 shows examples of the seasonal cycles evaluated for the instruments considered. For instruments with coarse temporal and horizontal sampling, GOMOS and ACE-FTS, the seasonal cycle is evaluated less reliably. There are biases between instruments, which are in agreement with earlier validation and intercomparison results (Hubert et al., 2016; Rahpoe et al., 2015; Sofieva et al., 2017). Since the seasonal cycle for SAGE II and OMPS is evaluated using the periods different for that used for the Ozone_cci instruments, we added a corrected seasonal cycle (dashed lines in Fig. 3): 

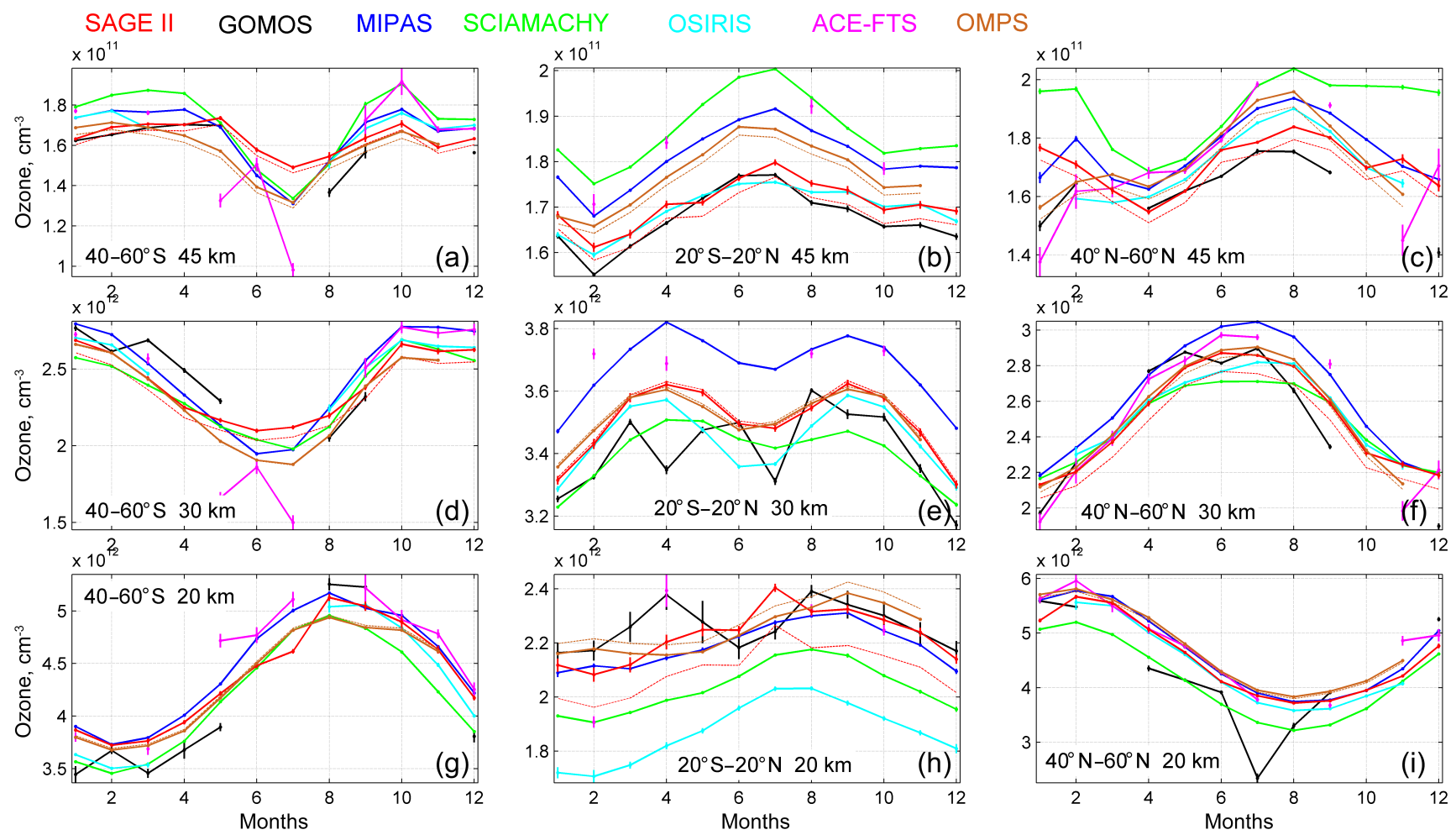

Figure 3. Ozone seasonal cycle for latitudes $40-60^{\circ} \mathrm{S}(\mathbf{a}, \mathbf{d}, \mathbf{g}), 20^{\circ} \mathrm{S}-20^{\circ} \mathrm{N}(\mathbf{b}, \mathbf{e}, \mathbf{h})$ and $40-60^{\circ} \mathrm{N}(\mathbf{c}, \mathbf{f}$, i), for altitudes $45 \mathrm{~km}(\mathbf{a}-\mathbf{c})$, $30 \mathrm{~km}(\mathbf{d}-\mathbf{f})$ and $20 \mathrm{~km}(\mathbf{g}-\mathbf{i})$. Error bars are $2 \sigma$ uncertainties according to Eq. (5). Dashed lines indicate corrected seasonal cycle for SAGE II and OMPS, see text for explanation. The seasonal cycles in the indicated zones are computed as the mean of seasonal cycles in $10^{\circ}$ latitude bands.

$\rho$ SAGE, $\operatorname{corr}(m)$

$=\rho_{\mathrm{SAGE}}(m) \cdot \frac{\rho_{\mathrm{SAGE}}, 2002-2004}{\rho_{\mathrm{SAGE}}, 1985-2004} \cdot \frac{\rho_{\text {OSIRIS, 2005-2011 }}}{\rho_{\text {OSIRIS, 2002-2004 }}} \quad$ and

$\rho_{\text {OMPS }, \operatorname{corr}}(m)=\rho_{\text {OMPS }}(m) \cdot \frac{\rho_{\text {OSIRIS, 2005-2011 }}}{\rho_{\text {OSIRIS, 2012-2016 }}}$

where $\rho_{\text {instrument, time_period }}$ is the average ozone for the indicated instrument and time period. (Note that this correction is not used in the merging algorithm, it is applied only for illustration in Fig. 3.) The small overall biases with respect to SAGE II data are observed for OSIRIS and GOMOS (except in tropics at $20 \mathrm{~km}$ ). Very good agreement between these instruments is also reported in several previous studies (Adams et al., 2013, 2014; Hubert et al., 2016; Kyrölä et al., 2013).

The uncertainty of the seasonal cycle value $\sigma_{\mathrm{m}}$ for each month $\mathrm{m}$ is evaluated from uncertainties of individual monthly mean values $\sigma_{\rho, j}$ :

$\sigma_{\mathrm{m}}^{2}=\frac{1}{N_{\mathrm{m}}^{2}} \sum_{j=1}^{N_{\mathrm{m}}} \sigma_{\rho, j}^{2}$,

which describes the propagation of the random uncertainties to the mean value. We would like to note that there is a signif- icant interannual variability of ozone due to geophysical processes (which can be characterized through a multiple linear regression with different proxies). These geophysical variations between different monthly values for a particular month are not characterized by Eq. (5).

The amplitude and phase of the seasonal cycle is very similar for SAGE II, MIPAS, SCIAMACHY, OSIRIS and OMPS, as illustrated in Fig. 4, which shows the normalized seasonal cycle. The SCIAMACHY seasonal cycle is slightly different at $45 \mathrm{~km}$ at northern midlatitudes. This is caused by the altitude interpolation error, which is especially crucial at midlatitudes in the upper stratosphere due to changing from semiannual (above this altitude) to annual (below this altitude) variation regime. Due to a coarse altitude retrieval grid, SCIAMACHY data are more sensitive to the selected type of the interpolation than other instruments. When using a log-linear interpolation, very similar results as for MIPAS are obtained in the upper stratosphere. SAGE II seasonal cycle in the middle and upper stratosphere in the latitude band $40-60^{\circ} \mathrm{S}$ has significantly lower amplitude than those of other instruments, especially at $45 \mathrm{~km}$, probably because of the sampling.

After the removal of the seasonal cycle, the SAGE II deseasonalized anomalies are offset to the Ozone_cci mean 

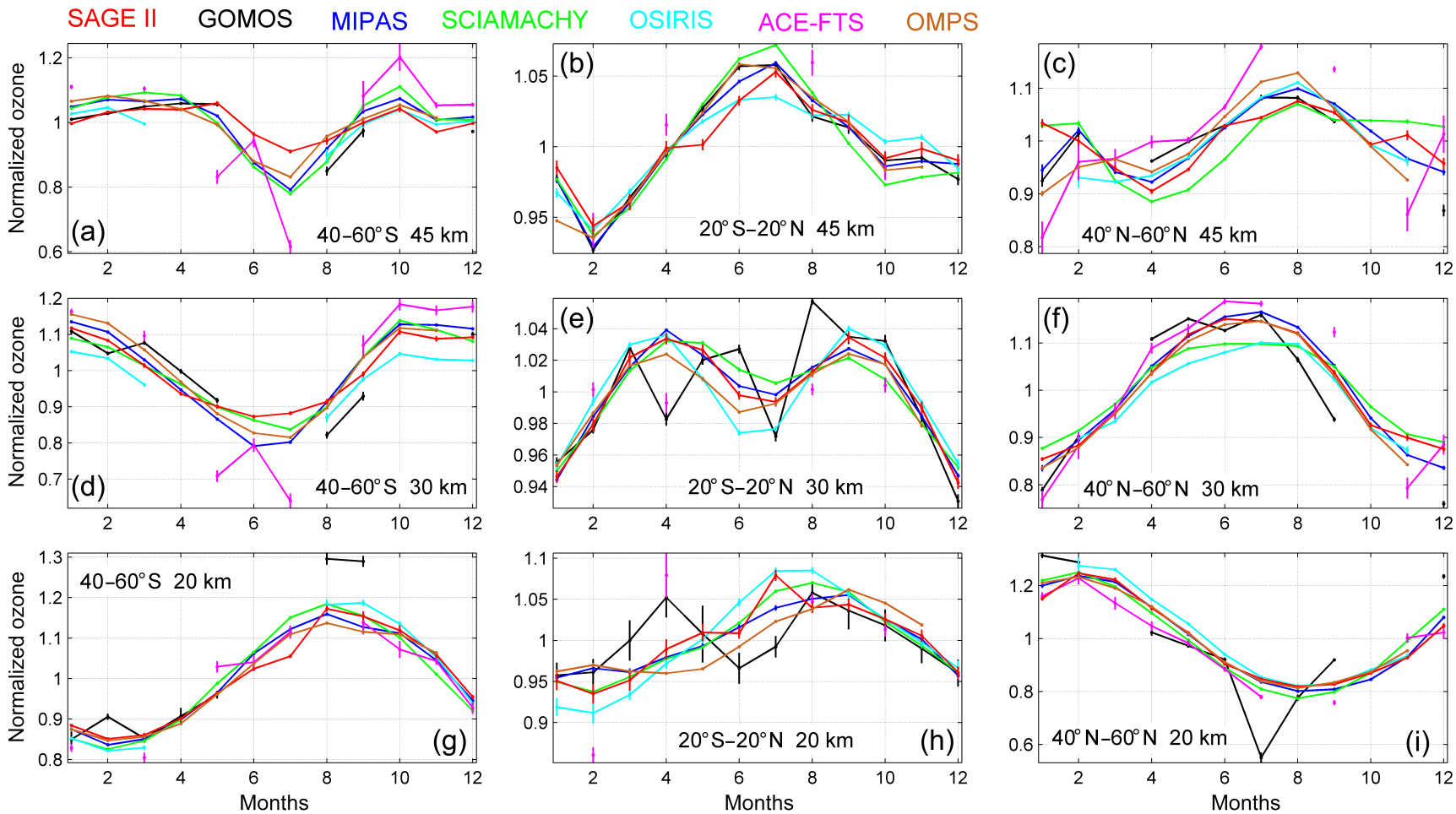

Figure 4. Ozone seasonal cycle normalized on the mean ozone value for latitudes $40-60^{\circ} \mathrm{S}(\mathbf{a}, \mathbf{d}, \mathbf{g}), 20^{\circ} \mathrm{S}-20^{\circ} \mathrm{N}\left(\mathbf{b}\right.$, e, h) and $40-60^{\circ} \mathrm{N}(\mathbf{c}$, $\mathbf{f}, \mathbf{i})$, for altitudes $45 \mathrm{~km}(\mathbf{a}-\mathbf{c}), 30 \mathrm{~km}(\mathbf{d}-\mathbf{f})$ and $20 \mathrm{~km}(\mathbf{g}-\mathbf{i})$. Error bars are $2 \sigma$ uncertainties according to Eq. (5).

anomalies in the years 2002-2005. The OMPS deseasonalized anomalies are offset to the mean Ozone_cci anomalies (which are based on OSIRIS and ACE-FTS measurements in this period) in the years 2012-2016. As a result, small offsets in SAGE II and OMPS anomalies due to the different reference time periods for evaluation of the seasonal cycle are removed, and the anomalies from all instruments are aligned.

Before merging, the deseasonalized anomalies of the individual instruments have been extensively intercompared with each other by computing and visualizing the time series of difference of individual anomalies from the median anomaly. This method turns out to be a sensitive method for detecting an unusual time series behavior of the individual data records. In particular, it was found that SCIAMACHY anomalies are larger in the beginning of the mission, for nearly all latitude bands and many altitude levels (see Fig. S3 in the Supplement, which shows the deviations of the SCIAMACHY deseasonalized anomalies from the median deseasonalized anomalies of SAGE II, GOMOS, MIPAS, SCIAMACHY, OSIRIS, ACE-FTS and OMPS). This might be attributed to possible pointing problems in the beginning of the mission; therefore we decided not to use the SCIAMACHY data before August 2003 in the merged dataset. Similarly, OMPS anomalies are lower in the first 3 months of the mission (see Fig. S6 in the Supplement); this might be related to relatively coarse sampling of OMPS in the first 3 months of the mission and possible problems with pointing. There- fore, OMPS data were included in the merged dataset starting from April 2012, when the instrument operated in its full capacity.

After the data selection, the anomalies from individual instruments are found to be in good agreement with each other. This is illustrated in Fig. 5, which shows the deviations of deseasonalized anomalies from each instrument relative to the median anomaly for latitudes $30-40^{\circ} \mathrm{S}$. The deviations from the median anomalies are small, less than $5 \%$ for the majority of data, and do not have statistically significant drifts with respect to the median anomaly (see also illustrations in the Supplement).

\section{The merged SAGE II-Ozone_cci-OMPS dataset}

We computed the merged anomaly as the median of the individual instruments anomalies, for each altitude level $z$ and for each latitude band $\theta$ and month $t$ :

$\Delta_{\text {merged }}(\theta, z, t)=\operatorname{median}\left(\Delta_{k}(\theta, z, t)\right)$,

where $\Delta_{k}$ indicates the individual instrument anomaly. Figure 6 illustrates the data merging: the upper panel shows the monthly zonal mean data, while the bottom panel shows individual anomalies and the merged (median) anomaly.

As observed in Fig. 6, the biases between the individual data records are removed by computing the deseason- 

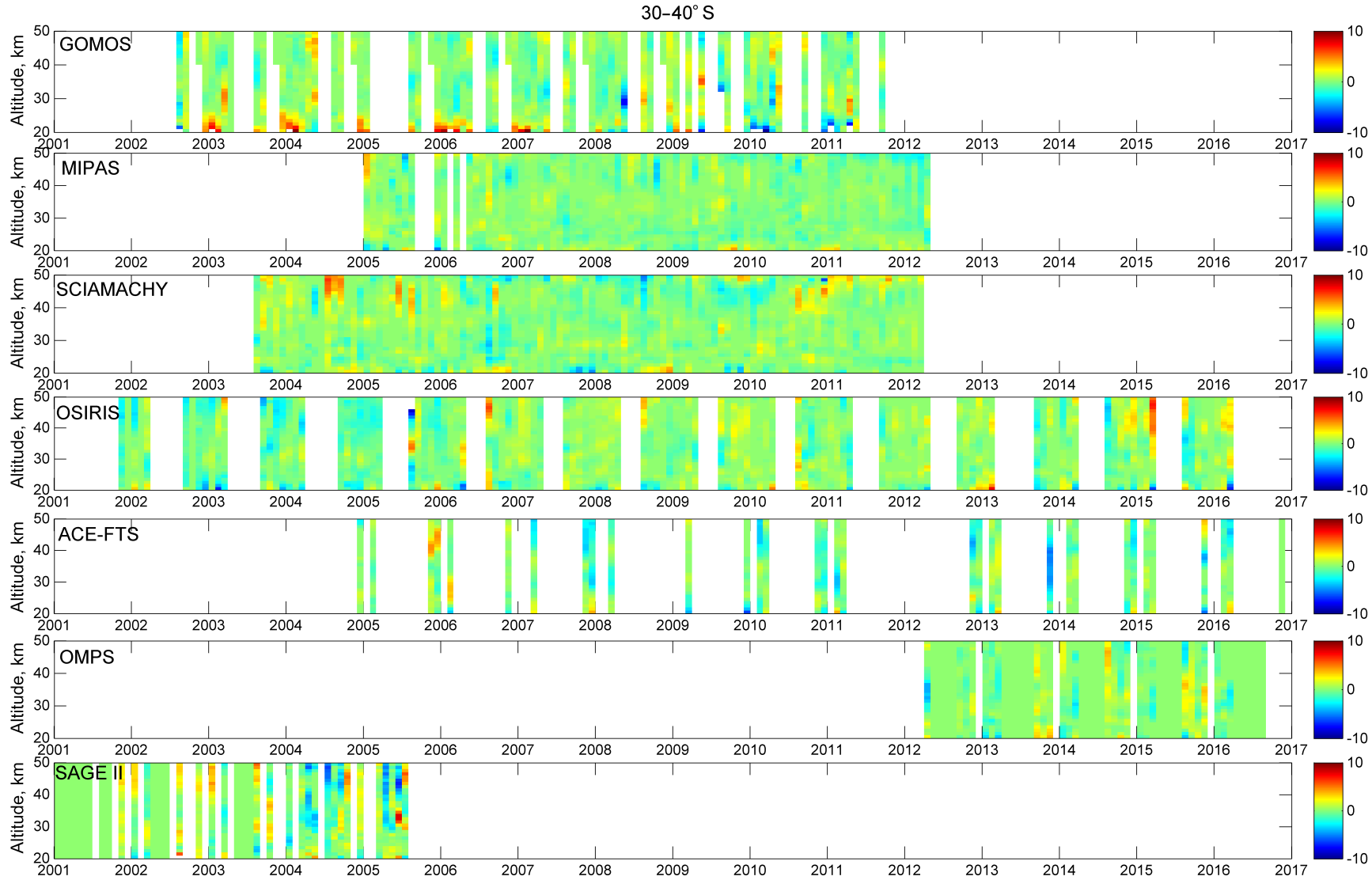

Figure 5. Deviations (in \%, color) of deseasonalized anomalies for GOMOS, MIPAS, SCIAMACHY, OSIRIS, ACE-FTS, OMPS and SAGE II (indicated in the panels) from the median deseasonalized anomalies computed using all datasets, $\Delta_{k}-\Delta_{\text {median }}$. Latitude band is $30-40^{\circ} \mathrm{S}$.

alized anomalies. In the merging, we filtered out individual anomaly values (locally for each latitude band and altitude level), which differ from the median anomaly more than $10 \%$ at latitudes $40^{\circ} \mathrm{S}-40^{\circ} \mathrm{N}$ and more than $20 \%$ in other latitude bands. This filtering does not affect the absolute majority of cases; it removes only a few exceptional anomalies from GOMOS and ACE-FTS, which are due to lower sampling.

An additional illustration of the very good agreement between the individual deseasonalized anomalies and the merged anomaly is presented in Fig. 7, which shows the correlation coefficient between the merged anomalies and individual anomalies using the years 2001-2016. The correlation coefficient is above 0.9 for all instruments in most of the latitude bands and altitude levels.

Examples of merged deseasonalized anomalies for several latitude bands are shown in Fig. 8. In the upper stratosphere at midlatitudes a decrease from 1984 to $1995-1999$ is observed, and then a gradual increase to the present. In the tropics, quasi-biennial oscillation (QBO) is observed.

The uncertainty of individual deseasonalized normalized anomalies $\sigma_{\Delta_{i}}$ (for each month and each latitude-altitude bin) can be estimated as

$\sigma_{\Delta i}=\frac{1}{\rho_{\mathrm{m}}} \sqrt{\sigma_{\rho, i}^{2}+\sigma_{\mathrm{m}}^{2}}$

where $\sigma_{\rho, i}$ is the uncertainty of the monthly zonal mean value from Eq. (2), and $\sigma_{\mathrm{m}}$ is uncertainty of the seasonal cycle from Eq. (5). We estimated the uncertainties of the merged deseasonalized anomalies (which correspond to median value) as

$\sigma_{\Delta, \text { merged }}=$

$\min \left(\sigma_{\Delta, j_{\text {med }}}, \sqrt{\frac{1}{N} \sum_{j=1}^{N} \sigma_{\Delta, j}^{2}+\frac{1}{N^{2}} \sum_{j=1}^{N}\left(\Delta_{j}-\Delta_{\text {merged }}\right)^{2}}\right)$,

where $\sigma_{\Delta, j_{\text {med }}}$ is the uncertainty of the anomaly of the instrument corresponding to the median value. Equation (7) can be interpreted as follows (see also Fig. A1 in Appendix). If individual anomalies are significantly different, i.e., the corresponding error bars do not intersect (Fig. A1, left), the uncertainty of the merged anomaly is the uncertainty corresponding to the median value. In case several instruments 

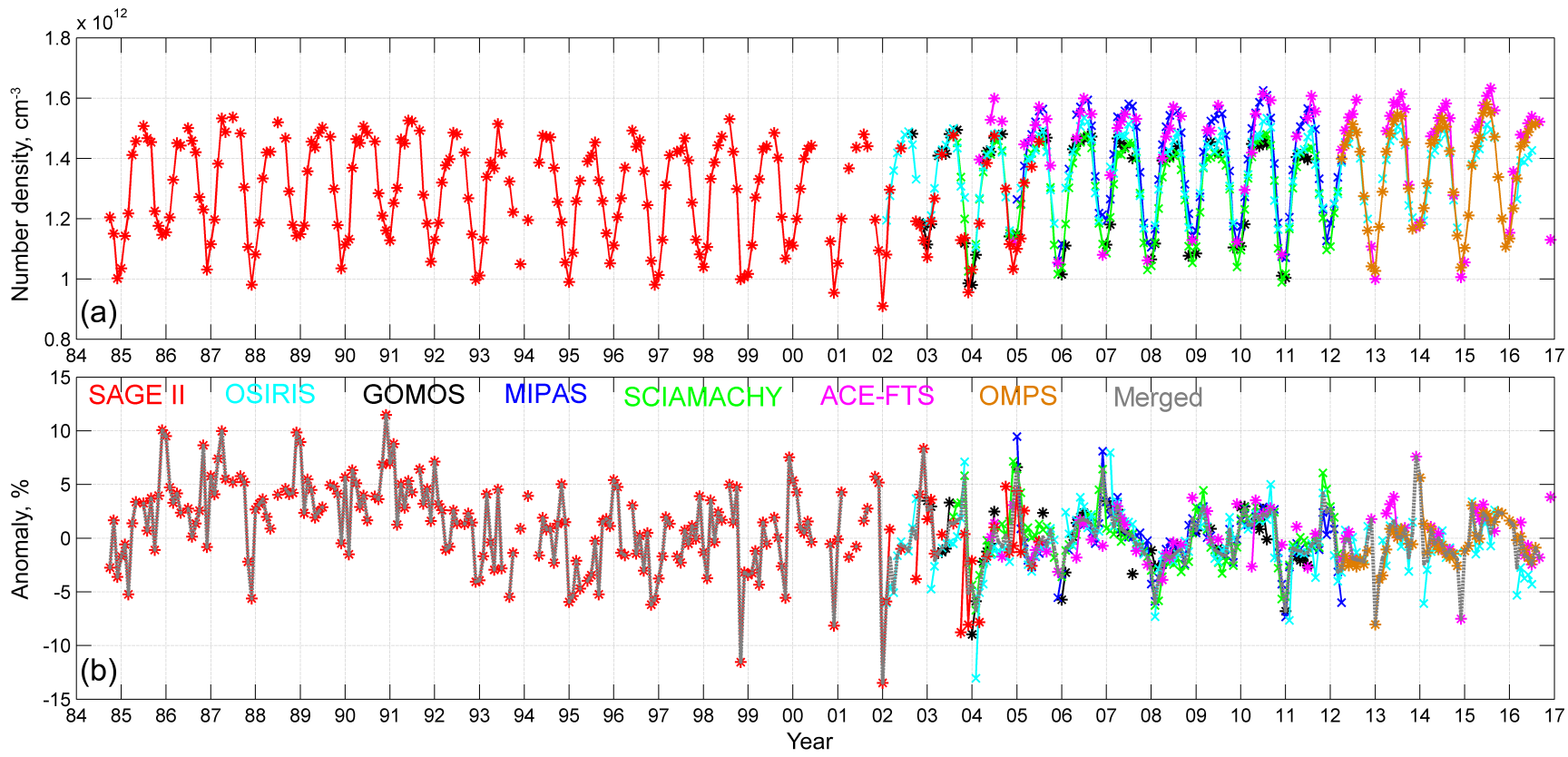

Figure 6. (a) Monthly zonal mean ozone at $35 \mathrm{~km}$ in the latitude band $40-50^{\circ} \mathrm{N}$. (b) Individual deseasonalized anomalies and the merged anomaly (grey line).
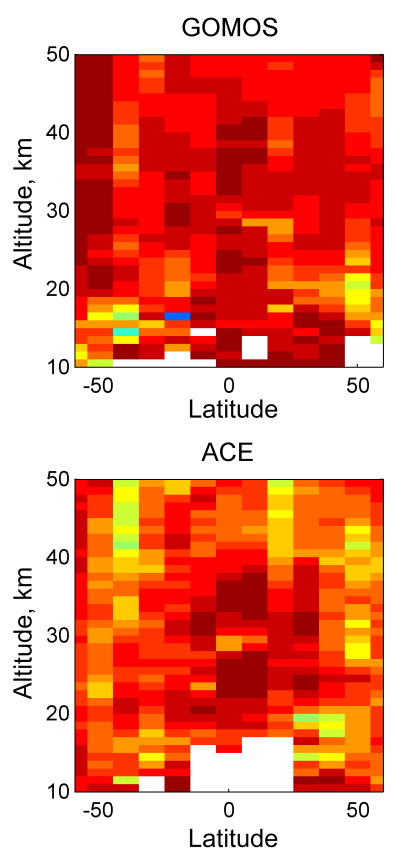

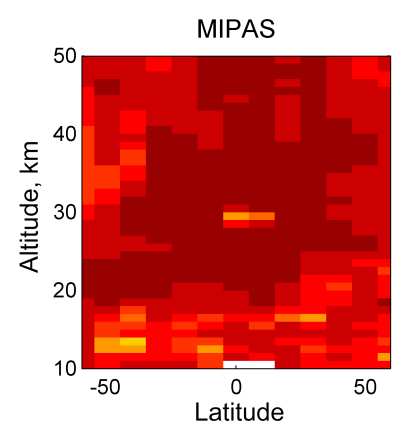

OMPS

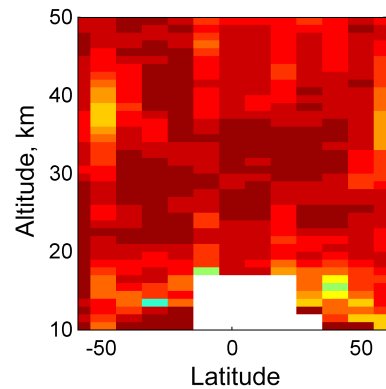

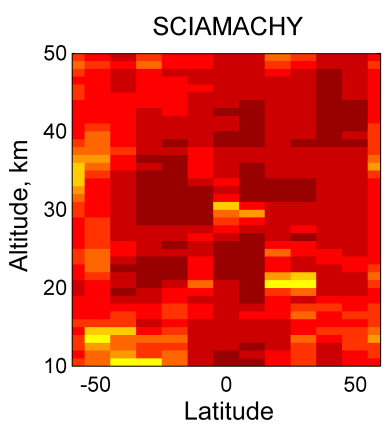
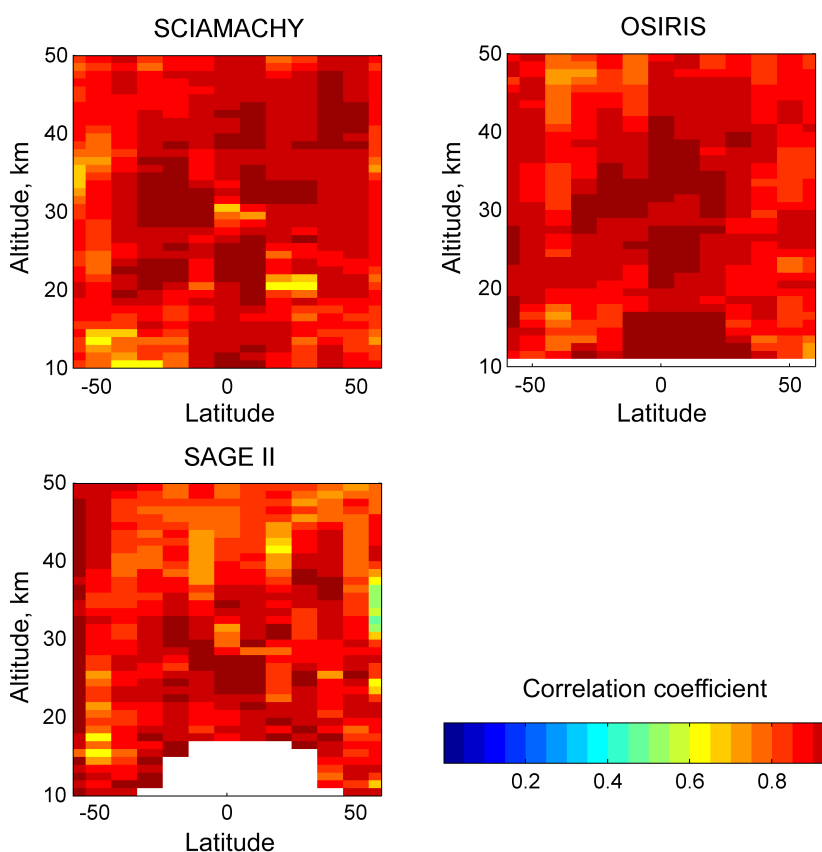

Figure 7. Correlation coefficient between individual and merged deseasonalized anomalies in the period $2001-2016$ at latitudes $60^{\circ} \mathrm{S}-60^{\circ} \mathrm{N}$

report a similar anomaly (intersecting error bars), this provides more confidence of this anomaly value, and the resulting uncertainty of the merged anomaly is approximated as $\sqrt{\frac{1}{N} \sum_{j=1}^{N} \sigma_{\Delta, j}^{2}+\frac{1}{N^{2}} \sum_{j=1}^{N}\left(\Delta_{j}-\Delta_{\text {merged }}\right)^{2}}$. For example, in the case of three coinciding anomalies with the same un- certainties $\sigma$, the uncertainty of the merged value will be $\sigma / \sqrt{3}$. For the considered datasets, anomalies are usually very close to each other, so that several values are within the $\Delta_{\text {merged }} \pm \sigma_{\Delta \text {, merged }}$ interval, as illustrated by Fig. S8 of the Supplement. 


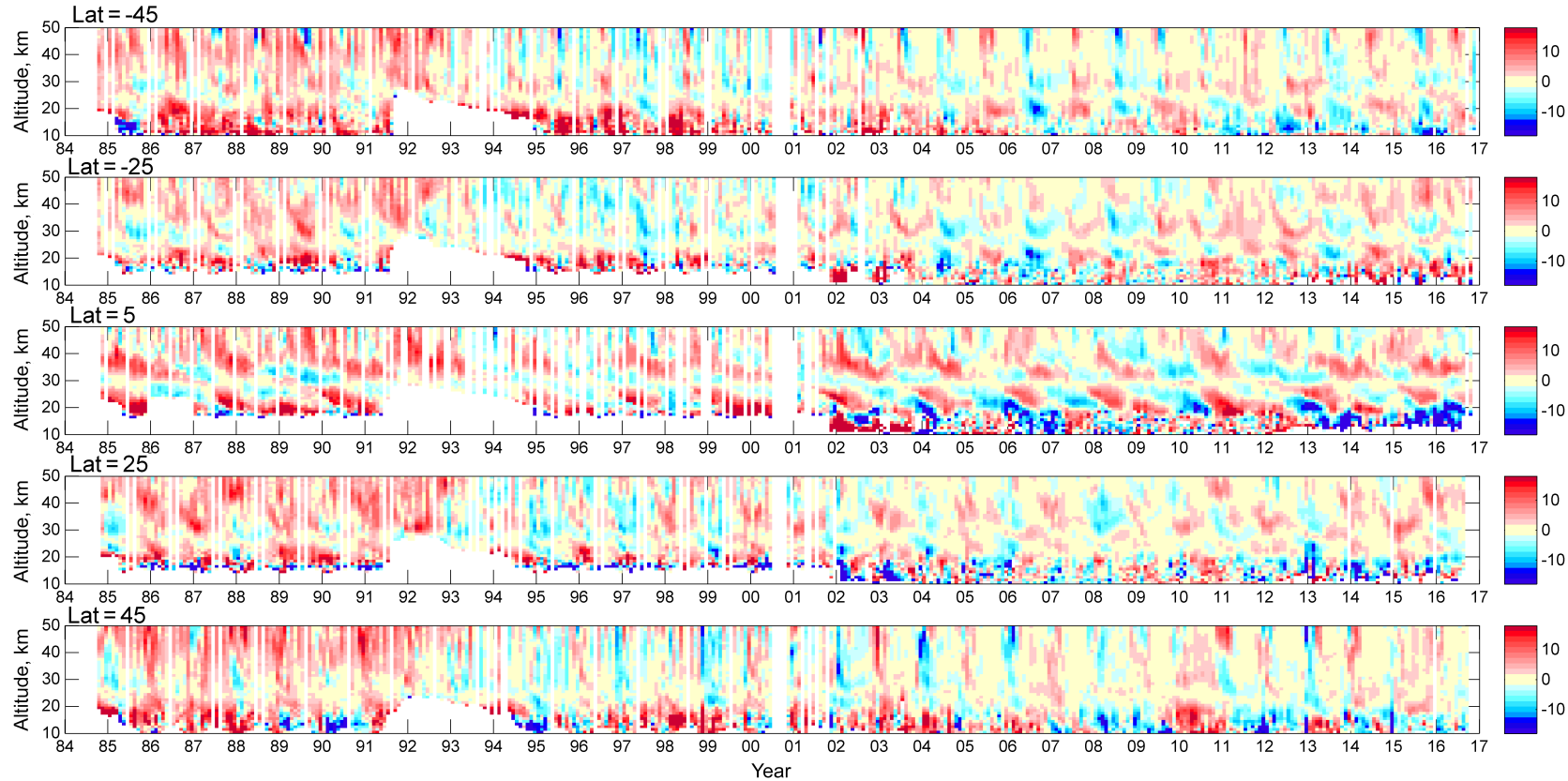

Figure 8. Examples of merged deseasonalized anomalies (color: \%), for several $10^{\circ}$ latitude bands, centers of which are specified in the legend.

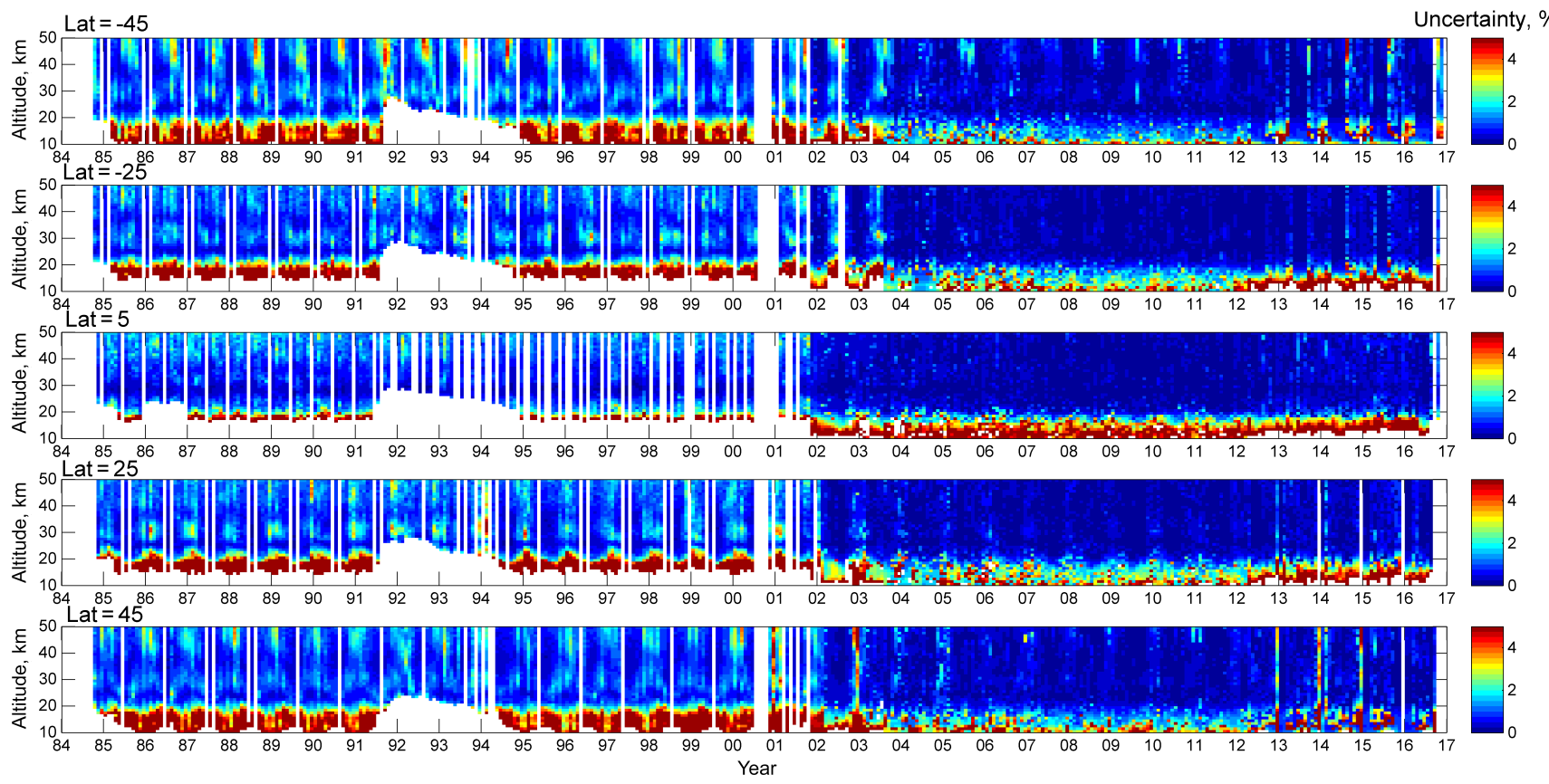

Figure 9. Uncertainties of the merged deseasonalized anomalies (\%), Eq. (8), for several $10^{\circ}$ latitude bands, centers of which are specified in the legend.

The uncertainty of the merged dataset is illustrated in Fig. 9 for the same latitude bands as shown in Fig. 8. As expected, the uncertainties in the time period when only SAGE II data were available are larger than uncertainties for time periods when several instruments have contributed. The average uncertainty is usually less than $4 \%$ before 2001 and below $1 \%$ for the years 2002-2017. In the UTLS, uncertainties are larger than in the stratosphere and are in the range of $3-9 \%$. At midlatitudes, uncertainties are larger in winter 
than in summer due to larger ozone variability during winter; this is observed clearly in the period before 2001 .

\section{Ozone trends}

The merged deseasonalized anomalies can be used directly for analyses of trends in the vertical distribution of ozone. For this purpose, a multivariate regression has been applied to the merged SAGE-CCI-OMPS data:

$$
\begin{aligned}
& \mathrm{O}_{3}(t)=\operatorname{PWLT}\left(t, t_{0}\right)+q_{1} \mathrm{QBO}_{30}(t)+q_{2} \mathrm{QBO}_{50}(t) \\
& +s F_{10.7}(t)+d \operatorname{ENSO}(t),
\end{aligned}
$$

where $\operatorname{PWLT}\left(t, t_{0}\right)$ is a piecewise linear term (constant and a hockey-stick trend with the turnaround point in 1997), $\mathrm{QBO}_{30}(t)$ and $\mathrm{QBO}_{50}(t)$ are the equatorial winds at 30 and $50 \mathrm{hPa}$, respectively (http://www.cpc.ncep.noaa. gov/data/indices/), $F_{10.7}(t)$ is the monthly average solar $10.7 \mathrm{~cm}$ radio flux (ftp://ftp.geolab.nrcan.gc.ca/data/solar_ flux/monthly_averages/), and $\operatorname{ENSO}(t)$ is the 2-month lagged ENSO proxy (http://www.esrl.noaa.gov/psd/enso/mei/table. html). As shown by Kyrölä et al. (2013) and Laine et al. (2014), the best estimate of the turnaround point is in 1997 for the majority of latitude bands and altitude levels. The sensitivity of regression results to the choice of turnaround point is discussed in Harris et al. (2015). Autocorrelations are removed using the Cochrane-Orcutt transformation (Cochrane and Orcutt, 1949).

Although uncertainties for the merged data are evaluated, they are not used in the regression analysis: different amounts of data available over time result in varying uncertainties over time (e.g., as shown in Fig. 9), which might improperly weight the time series. In our regression, all data points are considered with equal weights, and the uncertainty of the fitted parameters is estimated from the regression residuals.

The regression is performed for each latitude band and for each altitude level independently. The regression is similar to that used in Kyrölä et al. (2013). There are also other methods for evaluation of trends, e.g., using dynamical linear modeling (Laine et al., 2014). Since the main focus of our paper is generation of the merged SAGE-CCI-OMPS dataset, we selected a rather "standard" regression model (Eq. 9). A short discussion on the sensitivity of regression results to the choice of the regression model is presented below.

The linear ozone trends before 1997 and after 1997 are shown in Fig. 10. Shaded areas show regions where trends are statistically different from zero at the $95 \%$ level. In the period 1984-1997, statistically significant negative trends from -4 to $-8 \% \mathrm{dec}^{-1}$ are observed in the upper stratosphere. In the period 1997-2016, the ozone trends in the upper stratosphere are $\sim+2 \% \mathrm{dec}^{-1}$, and they are statistically different from zero at the $95 \%$ level in the extratropics. The ozone trends in large latitude bands, analogous to those studied in WMO (2014), Harris et al. (2015) and Steinbrecht et al. (2017), are shown in Fig. 11 (the anomalies in large latitude bands are created from $10^{\circ}$ latitude anomalies). The estimated ozone trends are consistent with previous results (Bourassa et al., 2014; Harris et al., 2015; Kyrölä et al., 2013; Tummon et al., 2015; WMO, 2014) and indicate that the ozone recovery has started. A slightly different ozone trend analysis using the SAGE-CCI-OMPS merged dataset by Steinbrecht et al. (2017) has resulted in nearly identical ozone trends (Fig. 3 in Steinbrecht et al., 2017), which indicates only a weak dependence of ozone trend estimates on the regression method (and collection of proxies).

To study the sensitivity of ozone trend results to filtering of suspicious data, we created a version of the merged dataset in the same way as above, but keeping the early periods of SCIAMACHY and OMPS operations, and performed the same analysis. Keeping all data results in very minor changes in ozone trends after 1997, as illustrated by Fig. S9 in the Supplement, the changes are mostly less than $0.3 \% \mathrm{dec}^{-1}$. This is not unexpected, because the median estimate used in data merging is insensitive to outliers.

Although conversion of mixing ratio to number density for MIPAS and ACE-FTS is performed using the retrieved temperature profiles, this might introduce a minor inconsistency. To evaluate a potential effect on ozone trends, we created a version of the merged dataset, but without MIPAS and ACE-FTS data. This merged dataset contains only data that were retrieved in number density on a geometric altitude grid. Minor changes $\left(<0.3 \% \mathrm{dec}^{-1}\right.$ at latitudes $40^{\circ} \mathrm{S}-40^{\circ} \mathrm{N}$, up to $\sim 1 \% \mathrm{dec}^{-1}$ at $40-60^{\circ} \mathrm{S}$ and $40-60^{\circ} \mathrm{N}$ ) in ozone trends after 1997 are observed (Fig. S10 in the Supplement). The effect is rather small because MIPAS operated in 2005-2012, when other datasets are also available, and the coverage by ACE-FTS is limited. Furthermore, anomalies from individual datasets are in good agreement with each other, and therefore significant changes in evaluated ozone trends are not expected.

The satellite data quality degrades in the UTLS. The merging principle seems to be optimal also for the UTLS, as it automatically removes biases, which can be significant in this region. The trends in the UTLS estimated using the merged SAGE-CCI-OMPS data follow the expected trend (declining ozone in the tropics just above the tropopause due to intensification of the Brewer-Dobson circulation). This is also in agreement with the dedicated studies on ozone trends in the tropical UTLS (e.g., Sioris et al., 2014).

\section{Summary}

We have presented the merged dataset of ozone profiles from several satellite instruments: SAGE II on ERBS, GOMOS, SCIAMACHY and MIPAS on Envisat, OSIRIS on Odin, ACE-FTS on SCISAT, and OMPS on Suomi-NPP. The merged dataset has been created with the aim of analyzing ozone trends in the stratosphere. For the merged dataset, we used the most recent retrieval versions of the satellite 
(a)

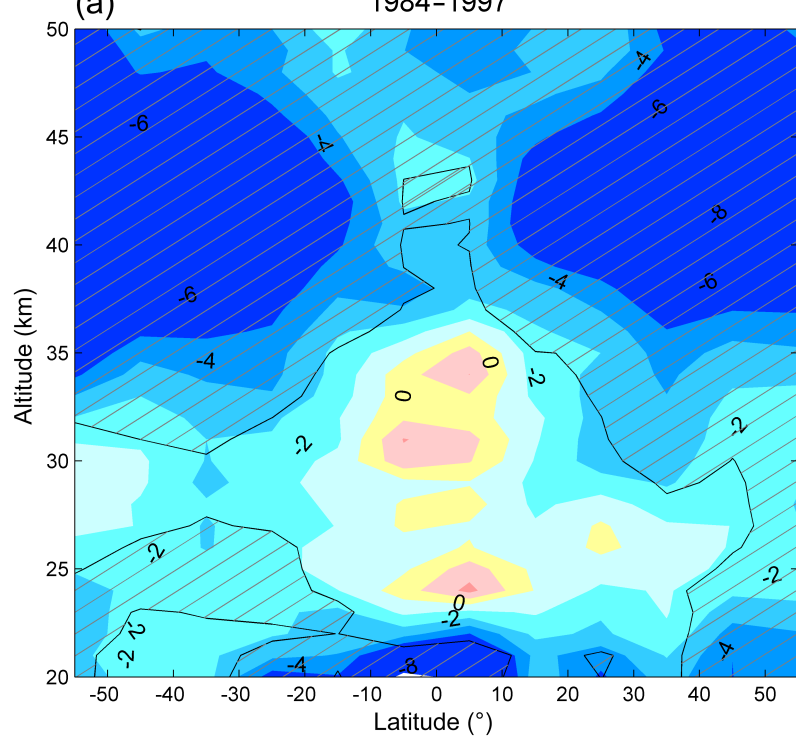

(b)

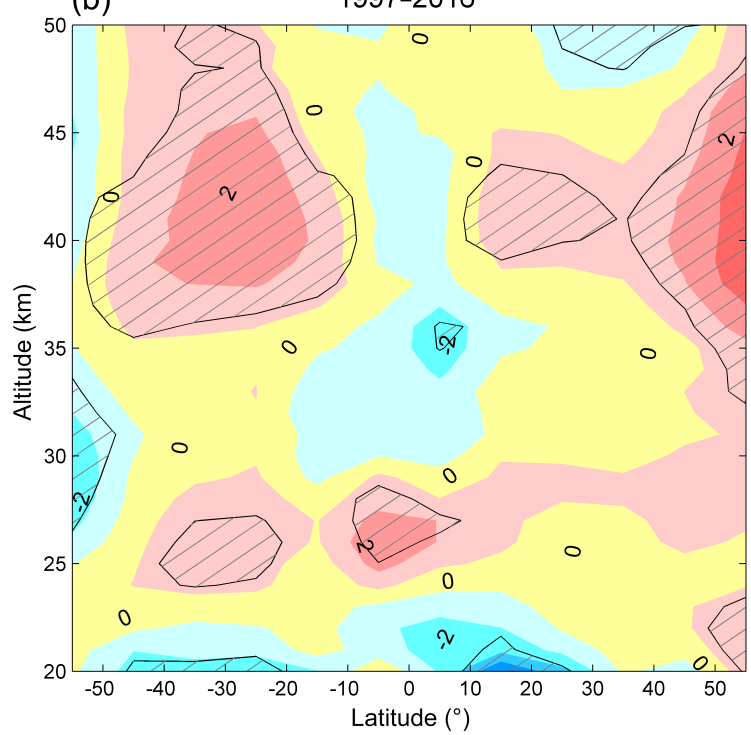

Trend

$\% \operatorname{dec}^{-1}$

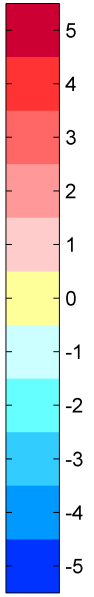

Figure 10. The ozone trend (\% decade ${ }^{-1}$ ) for different latitudes for 1984-1997 (a) and 1997-2016 (b). Shaded areas show regions where trends are statistically different from zero at the $95 \%$ level.
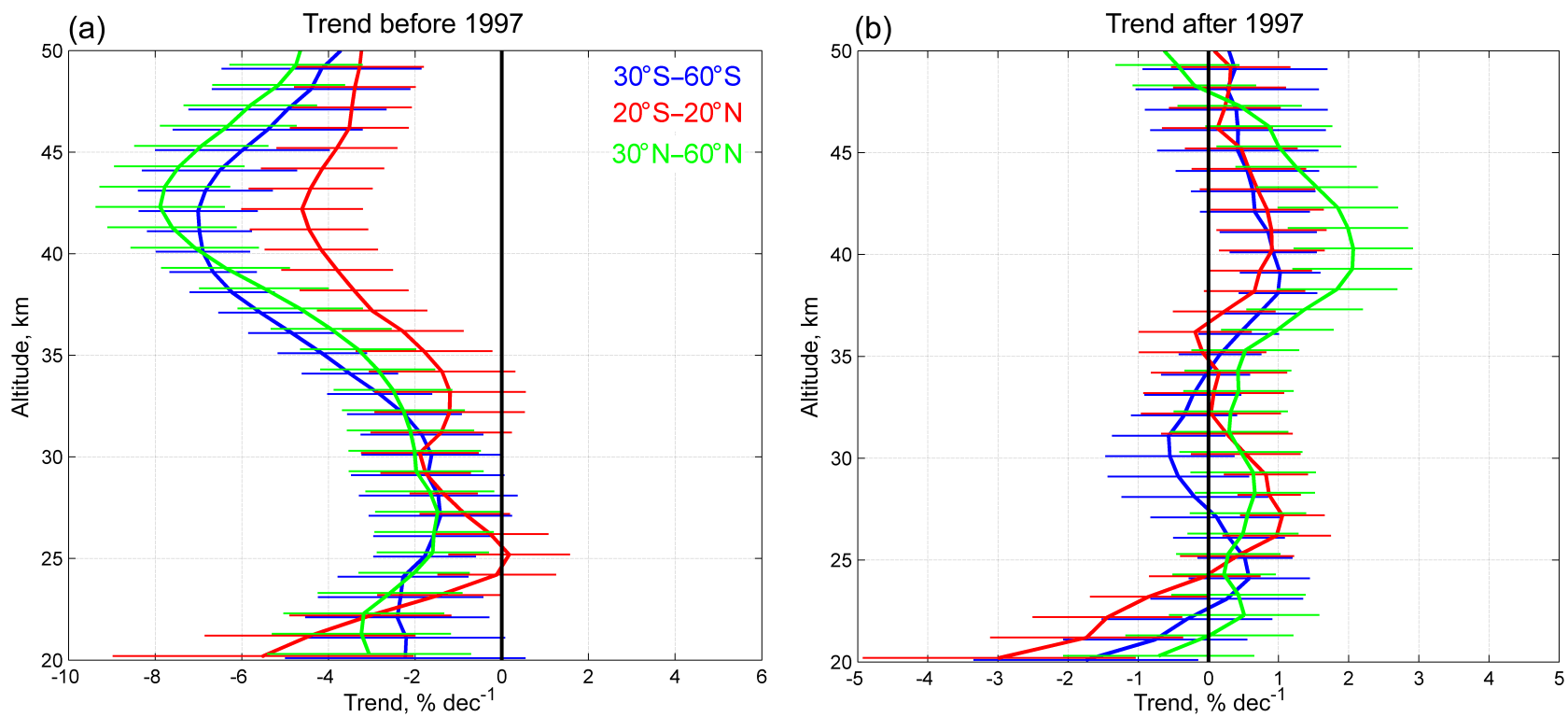

Figure 11. Vertical profiles of ozone trends obtained by the multiple regression Eq. (9), in 1984-1997 (a) and in 1998-2016 (b), for broad latitude bands. Error bars are $2 \sigma$ uncertainties.

datasets. The datasets from the individual instruments have been extensively validated and intercompared; only datasets which are in good agreement, and do not exhibit drifts with respect to collocated ground-based observations and with respect to each other, are used for merging.

The long-term SAGE-CCI-OMPS dataset is created by computation and merging of deseasonalized anomalies from individual instruments and associated uncertainties of the merged data are estimated. The merged SAGE-CCI-OMPS dataset consists of deseasonalized ozone anomalies in $10^{\circ}$ latitude bands from $90^{\circ} \mathrm{S}$ to $90^{\circ} \mathrm{N}$. The data are provided on an altitude grid from 10 to $50 \mathrm{~km}$ covering the period from October 1984 to July 2016.

Ozone trends in the stratosphere are evaluated by applying a multiple linear regression to the merged SAGE-CCIOMPS dataset. Negative ozone trends in the upper stratosphere before 1997 and positive trends after 1997 are ob- 
served. The upper stratospheric trends in the extratropics are statistically significant and indicate onset of ozone recovery.

Data availability. The main dataset consists of the merged deseasonalized anomalies and their uncertainties described above. For the purpose of other applications (e.g., comparisons with models), we also present merged ozone concentration profiles. The details of computing merged number density profiles from the merged de- seasonalized anomalies are presented in the Supplement. It is performed according to Eq. (4) by restoring the seasonal cycle. For trend analyses, it is recommended using the deseasonalized anomalies. According to the merging principle, the best quality of the merged dataset is in the stratosphere below $60^{\circ}$ latitude.

The merged SAGE II-Ozone_cci-OMPS dataset is available from http://www.esa-ozone-cci.org. The updates of the merged dataset will be provided when more recent data will be available. 


\section{Appendix A: Illustration of uncertainty of the merged deseasonalized anomalies}

Here we present the illustration of Eq. (8). Two different cases are shown; left: individual anomalies (colored error bars) are significantly different and the corresponding error bars do not intersect; right: nearly coinciding individual anomalies. Since the merged anomaly is simply the median value, in the case of significantly different anomalies (left), the uncertainty of the merged anomaly (black error bar) is the uncertainty corresponding to the median value (red in the considered example). If the number of instruments is even, the mean of the uncertainties corresponding to the nearest to the median values is taken. Several nearly coinciding anomalies from different independent instruments provide more confidence of this anomaly value, and the resulting uncertainty of the merged anomaly is approximated as

$\sigma_{\text {merged }}=\frac{1}{\sqrt{N}} \sqrt{\sum_{j=1}^{N} \sigma_{\Delta, j}^{2}+\frac{1}{N} \sum_{j=1}^{N}\left(\Delta_{j}-\Delta_{\text {merged }}\right)^{2}}$.

In the example shown in Fig. A1 (right), the uncertainty of the merged value is close to $\sigma / \sqrt{3}$ ( $\sigma$ is the uncertainty of each anomaly, the uncertainties are chosen to be the same for an illustration).

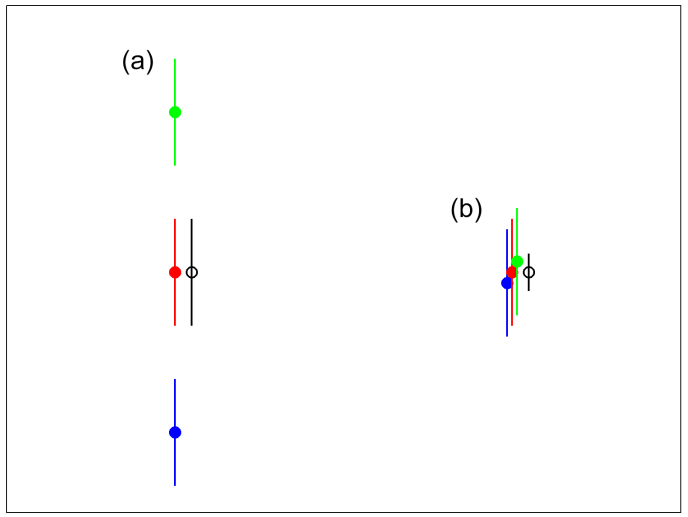

Figure A1. Schematic illustration (arbitrary $y$-axis scaling) of two extreme cases of individual anomalies and their uncertainties. Colored error bars: individual anomalies, black: merged (median) anomaly. (a) Significantly different individual anomalies with nonintersecting error bars, (b) nearly coinciding individual anomalies.

Equation (A1) can be also interpreted as follows. The expression under the square root represents the estimate of the standard deviation for small samples (SPARC, 2013), which, being divided by the square root of the number of measurements $\sqrt{N}$, gives the standard error of the mean. 


\section{The Supplement related to this article is available online at https://doi.org/10.5194/acp-17-12533-2017- supplement.}

Competing interests. The authors declare that they have no conflict of interest.

Special issue statement. This article is part of the special issue "Quadrennial Ozone Symposium 2016 - Status and trends of atmospheric ozone (ACP/AMT inter-journal SI)". It is a result of the Quadrennial Ozone Symposium 2016, Edinburgh, United Kingdom, 4-9 Sep 2016.

Acknowledgements. The work is performed in the framework of ESA Ozone_cci project. The KIT team would like to thank the European Space Agency (ESA) for giving access to MIPAS level-1 data. The SCIAMACHY ozone retrieval was funded in part by the ESA, German Aerospace Agency (DLR), University of Bremen and state of Bremen. The dataset was calculated with resources provided by the North-German Supercomputing Alliance (HLRN). The GOMOS ALGOM2s dataset was created in the framework of ESA ALGOM project. The FMI team thanks the Academy of Finland (INQUIRE project). The ACE mission is supported primarily by the Canadian Space Agency (CSA). Odin is a Swedish-led satellite project funded jointly by Sweden (SNSB), Canada (CSA), France (CNES) and Finland (Tekes).

Edited by: Richard Eckman

Reviewed by: two anonymous referees

\section{References}

Adams, C., Bourassa, A. E., Bathgate, A. F., McLinden, C. A., Lloyd, N. D., Roth, C. Z., Llewellyn, E. J., Zawodny, J. M., Flittner, D. E., Manney, G. L., Daffer, W. H., and Degenstein, D. A.: Characterization of Odin-OSIRIS ozone profiles with the SAGE II dataset, Atmos. Meas. Tech., 6, 1447-1459, https://doi.org/10.5194/amt-6-1447-2013, 2013.

Adams, C., Bourassa, A. E., Sofieva, V., Froidevaux, L., McLinden, C. A., Hubert, D., Lambert, J.-C., Sioris, C. E., and Degenstein, D. A.: Assessment of Odin-OSIRIS ozone measurements from 2001 to the present using MLS, GOMOS, and ozonesondes, Atmos. Meas. Tech., 7, 49-64, https://doi.org/10.5194/amt-7-492014, 2014.

Bernath, P. F.: The Atmospheric Chemistry Experiment (ACE), J. Quant. Spectrosc. Ra., 186, 3-16, https://doi.org/10.1016/j.jqsrt.2016.04.006, 2017.

Bernath, P. F., McElroy, C. T., Abrams, M. C., Boone, C. D., Butler, M., Camy-Peyret, C., Carleer, M., Clerbaux, C., Coheur, P.F., Colin, R., DeCola, P., DeMazière, M., Drummond, J. R., Dufour, D., Evans, W. F. J., Fast, H., Fussen, D., Gilbert, K., Jennings, D. E., Llewellyn, E. J., Lowe, R. P., Mahieu, E., McConnell, J. C., McHugh, M., McLeod, S. D., Michaud, R., Midwinter, C., Nassar, R., Nichitiu, F., Nowlan, C., Rinsland, C. P.,
Rochon, Y. J., Rowlands, N., Semeniuk, K., Simon, P., Skelton, R., Sloan, J. J., Soucy, M.-A., Strong, K., Tremblay, P., Turnbull, D., Walker, K. A., Walkty, I., Wardle, D. A., Wehrle, V., Zander, R., and Zou, J.: Atmospheric Chemistry Experiment (ACE): mission overview, Geophys. Res. Lett., 32, L15S01, https://doi.org/10.1029/2005GL022386, 2005.

Bertaux, J. L., Kyrölä, E., Fussen, D., Hauchecorne, A., Dalaudier, F., Sofieva, V., Tamminen, J., Vanhellemont, F., Fanton d'Andon, O., Barrot, G., Mangin, A., Blanot, L., Lebrun, J. C., Pérot, K., Fehr, T., Saavedra, L., Leppelmeier, G. W., and Fraisse, R.: Global ozone monitoring by occultation of stars: an overview of GOMOS measurements on ENVISAT, Atmos. Chem. Phys., 10, 12091-12148, https://doi.org/10.5194/acp-10-12091-2010, 2010.

Bingen, C. and Fussen, D.: Structure and spectral features of the stratospheric aerosol extinction profiles in the UV-visible range derived from SAGE II data, J. Geophys. Res.-Atmos., 105, 47674776, https://doi.org/10.1029/1999JD901109, 2000.

Boone, C. D., Nassar, R., Walker, K. A., Rochon, Y., McLeod, S. D., Rinsland, C. P., and Bernath, P. F.: Retrievals for the atmospheric chemistry experiment Fourier-transform spectrometer, Appl. Optics, 44, 7218-7231, 2005.

Boone, C. D., Walker, K. A., and Bernath, P. F.: Version 3 retrievals for the Atmospheric Chemistry Experiment Fourier Transform Spectrometer (ACE-FTS), in: The Atmospheric Chemistry Experiment ACE at 10: A Solar Occultation Anthology, edited by: Bernath, P. F., A. Deepak Publishing, Hampton, Virginia, USA, 103-127, 2013.

Bourassa, A. E., Degenstein, D. A., Randel, W. J., Zawodny, J. M., Kyrölä, E., McLinden, C. A., Sioris, C. E., and Roth, C. Z.: Trends in stratospheric ozone derived from merged SAGE II and Odin-OSIRIS satellite observations, Atmos. Chem. Phys., 14, 6983-6994, https://doi.org/10.5194/acp-14-6983-2014, 2014.

Bourassa, A. E., Roth, C. Z., Zawada, D. J., Rieger, L. A., McLinden, C. A., and Degenstein, D. A.: Drift corrected Odin-OSIRIS ozone product: algorithm and updated stratospheric ozone trends, Atmos. Meas. Tech. Discuss., https://doi.org/10.5194/amt-2017229, in review, 2017.

Bovensmann, H., Burrows, J. P., Buchwitz, M., Frerick, J., Noël, S., Rozanov, V. V, Chance, K. V., and Goede, A. P. H.: SCIAMACHY: mission objectives and measurement modes, J. Atmos. Sci., 56, 127-150, https://doi.org/10.1175/15200469(1999)056<0127:SMOAMM>2.0.CO;2, 1999.

Burrows, J. P., Hölzle, E., Goede, A. P. H., Visser, H., and Fricke, W.: SCIAMACHY - scanning imaging absorption spectrometer for atmospheric chartography, Acta Astronaut., 35, 445-451, https://doi.org/10.1016/0094-5765(94)00278-T, 1995.

Chu, W. P., McCormick, M. P., Lenoble, J., Brogniez, C., and Pruvost, P.: SAGE-II inversion algorithm, J. Geophys. Res., 94, 8339-8351, https://doi.org/10.1029/JD094iD06p08339, 1989.

Cochrane, D. and Orcutt, G. H.: Application of least squares regression to relationships containing autocorrelated error terms, J. Am. Stat. Assoc., 44, 32-61, https://doi.org/10.1080/01621459.1949.10483290, 1949.

Damadeo, R. P., Zawodny, J. M., Thomason, L. W., and Iyer, N.: SAGE version 7.0 algorithm: application to SAGE II, Atmos. Meas. Tech., 6, 3539-3561, https://doi.org/10.5194/amt-6-35392013, 2013. 
Damadeo, R. P., Zawodny, J. M., and Thomason, L. W.: Reevaluation of stratospheric ozone trends from SAGE II data using a simultaneous temporal and spatial analysis, Atmos. Chem. Phys., 14, 13455-13470, https://doi.org/10.5194/acp-14-134552014, 2014.

Davis, S. M., Rosenlof, K. H., Hassler, B., Hurst, D. F., Read, W. G., Vömel, H., Selkirk, H., Fujiwara, M., and Damadeo, R.: The Stratospheric Water and Ozone Satellite Homogenized (SWOOSH) database: a long-term database for climate studies, Earth Syst. Sci. Data, 8, 461-490, https://doi.org/10.5194/essd8-461-2016, 2016.

Degenstein, D. A., Bourassa, A. E., Roth, C. Z., and Llewellyn, E. J.: Limb scatter ozone retrieval from 10 to $60 \mathrm{~km}$ using a multiplicative algebraic reconstruction technique, Atmos. Chem. Phys., 9, 6521-6529, https://doi.org/10.5194/acp-9-6521-2009, 2009.

Eckert, E., von Clarmann, T., Kiefer, M., Stiller, G. P., Lossow, S., Glatthor, N., Degenstein, D. A., Froidevaux, L., GodinBeekmann, S., Leblanc, T., McDermid, S., Pastel, M., Steinbrecht, W., Swart, D. P. J., Walker, K. A., and Bernath, P. F.: Drift-corrected trends and periodic variations in MIPAS IMK/IAA ozone measurements, Atmos. Chem. Phys., 14, 25712589, https://doi.org/10.5194/acp-14-2571-2014, 2014.

Fischer, H., Birk, M., Blom, C., Carli, B., Carlotti, M., von Clarmann, T., Delbouille, L., Dudhia, A., Ehhalt, D., Endemann, M., Flaud, J. M., Gessner, R., Kleinert, A., Koopman, R., Langen, J., López-Puertas, M., Mosner, P., Nett, H., Oelhaf, H., Perron, G., Remedios, J., Ridolfi, M., Stiller, G., and Zander, R.: MIPAS: an instrument for atmospheric and climate research, Atmos. Chem. Phys., 8, 2151-2188, https://doi.org/10.5194/acp-8-21512008, 2008.

Flynn, L. E., Seftor, C. J., Larsen, J. C., and Xu, P.: The ozone mapping and profiler suite, in: Earth Science Satellite Remote Sensing: Vol. 1: Science and Instruments, edited by: Qu, J. J., Gao, W., Kafatos, M., Murphy, R. E., and Salomonson, V. V., Springer, Berlin, Heidelberg, 279-296, 2006.

Froidevaux, L., Anderson, J., Wang, H.-J., Fuller, R. A., Schwartz, M. J., Santee, M. L., Livesey, N. J., Pumphrey, H. C., Bernath, P. F., Russell III, J. M., and McCormick, M. P.: Global OZone Chemistry And Related trace gas Data records for the Stratosphere (GOZCARDS): methodology and sample results with a focus on $\mathrm{HCl}, \mathrm{H}_{2} \mathrm{O}$, and $\mathrm{O}_{3}$, Atmos. Chem. Phys., 15, 1047110507, https://doi.org/10.5194/acp-15-10471-2015, 2015.

Fussen, D. and Bingen, C.: A volcanism dependent model for the extinction profile of stratospheric aerosols in the UV-visible range, Geophys. Res. Lett., 26, 703-706, https://doi.org/10.1029/1999GL900082, 1999.

Harris, N. R. P., Hassler, B., Tummon, F., Bodeker, G. E., Hubert, D., Petropavlovskikh, I., Steinbrecht, W., Anderson, J., Bhartia, P. K., Boone, C. D., Bourassa, A., Davis, S. M., Degenstein, D., Delcloo, A., Frith, S. M., Froidevaux, L., Godin-Beekmann, S., Jones, N., Kurylo, M. J., Kyrölä, E., Laine, M., Leblanc, S. T., Lambert, J.-C., Liley, B., Mahieu, E., Maycock, A., de Mazière, M., Parrish, A., Querel, R., Rosenlof, K. H., Roth, C., Sioris, C., Staehelin, J., Stolarski, R. S., Stübi, R., Tamminen, J., Vigouroux, C., Walker, K. A., Wang, H. J., Wild, J., and Zawodny, J. M.: Past changes in the vertical distribution of ozone - Part 3: Analysis and interpretation of trends, At- mos. Chem. Phys., 15, 9965-9982, https://doi.org/10.5194/acp15-9965-2015, 2015.

Hubert, D., Lambert, J.-C., Verhoelst, T., Granville, J., Keppens, A., Baray, J.-L., Bourassa, A. E., Cortesi, U., Degenstein, D. A., Froidevaux, L., Godin-Beekmann, S., Hoppel, K. W., Johnson, B. J., Kyrölä, E., Leblanc, T., Lichtenberg, G., Marchand, M., McElroy, C. T., Murtagh, D., Nakane, H., Portafaix, T., Querel, R., Russell III, J. M., Salvador, J., Smit, H. G. J., Stebel, K., Steinbrecht, W., Strawbridge, K. B., Stübi, R., Swart, D. P. J., Taha, G., Tarasick, D. W., Thompson, A. M., Urban, J., van Gijsel, J. A. E., Van Malderen, R., von der Gathen, P., Walker, K. A., Wolfram, E., and Zawodny, J. M.: Ground-based assessment of the bias and long-term stability of 14 limb and occultation ozone profile data records, Atmos. Meas. Tech., 9, 2497-2534, https://doi.org/10.5194/amt-9-2497-2016, 2016.

IPCC: Climate Change 2013: The Physical Science Basis. Contribution of Working Group I to the Fifth Assessment Report of the Intergovernmental Panel on Climate Change, edited by: Stocker, T. F., Qin, D., Plattner, G.-K., Tignor, M., Allen, S. K., Boschung, J., Nauels, A., Xia, Y., Bex, V., and Midgley, P. M., Cambridge University Press, Cambridge, UK and New York, NY, USA, 1535 pp., https://doi.org/10.1017/CBO9781107415324, 2013.

Jones, A., Urban, J., Murtagh, D. P., Eriksson, P., Brohede, S., Haley, C., Degenstein, D., Bourassa, A., von Savigny, C., Sonkaew, T., Rozanov, A., Bovensmann, H., and Burrows, J.: Evolution of stratospheric ozone and water vapour time series studied with satellite measurements, Atmos. Chem. Phys., 9, 6055-6075, https://doi.org/10.5194/acp-9-6055-2009, 2009.

Kyrölä, E., Tamminen, J., Sofieva, V., Bertaux, J. L., Hauchecorne, A., Dalaudier, F., Fussen, D., Vanhellemont, F., Fanton d'Andon, O., Barrot, G., Guirlet, M., Mangin, A., Blanot, L., Fehr, T., Saavedra de Miguel, L., and Fraisse, R.: Retrieval of atmospheric parameters from GOMOS data, Atmos. Chem. Phys., 10, 1188111903, https://doi.org/10.5194/acp-10-11881-2010, 2010.

Kyrölä, E., Laine, M., Sofieva, V., Tamminen, J., Päivärinta, S.M., Tukiainen, S., Zawodny, J., and Thomason, L.: Combined SAGE II-GOMOS ozone profile data set for 1984-2011 and trend analysis of the vertical distribution of ozone, Atmos. Chem. Phys., 13, 10645-10658, https://doi.org/10.5194/acp-13-106452013, 2013.

Laeng, A., Eckert, E., von Clarmann, T., Kiefer, M., Hubert, D., Stiller, G., Grabowski, U., Glatthor, N., Plieninger, J., Kellmann, S., Linden, A., Lossow, S., Babenhauserheide, A., Froidevaux, L., and Walker, K.: On the improved stability of the version 7 MIPAS ozone record, Atmos. Meas. Tech., accepted, 2017.

Laine, M., Latva-Pukkila, N., and Kyrölä, E.: Analysing timevarying trends in stratospheric ozone time series using the state space approach, Atmos. Chem. Phys., 14, 9707-9725, https://doi.org/10.5194/acp-14-9707-2014, 2014.

Mauldin III, L. E., Zaun, N. H., McCormick Jr., M. P., Guy, J. H., and Vaughn, W. R.: Stratospheric aerosol and gas experiment II instrument: a functional description, Opt. Eng., 24, 242307242307, https://doi.org/10.1117/12.7973473, 1985.

McCormick, M. P., Zawodny, J. M., Veiga, R. E., Larsen, J. C., and Wang, P. H.: An overview of SAGE I and II ozone measurements, Planet. Space Sci., 37, 1567-1586, 1989.

Moy, L., Bhartia, P. K., Jaross, G., Loughman, R., Kramarova, N., Chen, Z., Taha, G., Chen, G., and Xu, P.: Altitude registration 
of limb-scattered radiation, Atmos. Meas. Tech., 10, 167-178, https://doi.org/10.5194/amt-10-167-2017, 2017.

Newchurch, M. J., Yang, E.-S., Cunnold, D. M., Reinsel, G. C., Zawodny, J. M., and Russell, J. M.: Evidence for slowdown in stratospheric ozone loss: first stage of ozone recovery, J. Geophys. Res.-Atmos., 108, 4507, https://doi.org/10.1029/2003JD003471, 2003.

Rahpoe, N., von Savigny, C., Weber, M., Rozanov, A. V., Bovensmann, H., and Burrows, J. P.: Error budget analysis of SCIAMACHY limb ozone profile retrievals using the SCIATRAN model, Atmos. Meas. Tech., 6, 2825-2837, https://doi.org/10.5194/amt-6-2825-2013, 2013.

Rahpoe, N., Weber, M., Rozanov, A. V., Weigel, K., Bovensmann, H., Burrows, J. P., Laeng, A., Stiller, G., von Clarmann, T., Kyrölä, E., Sofieva, V. F., Tamminen, J., Walker, K., Degenstein, D., Bourassa, A. E., Hargreaves, R., Bernath, P., Urban, J., and Murtagh, D. P.: Relative drifts and biases between six ozone limb satellite measurements from the last decade, Atmos. Meas. Tech., 8, 4369-4381, https://doi.org/10.5194/amt-8-4369-2015, 2015.

Randel, W. J. and Thompson, A. M.: Interannual variability and trends in tropical ozone derived from SAGE II satellite data and SHADOZ ozonesondes, J. Geophys. Res., 116, D07303, https://doi.org/10.1029/2010JD015195, 2011.

Randel, W. J., Shine, K. P., Austin, J., Barnett, J., Claud, C., Gillett, N. P., Keckhut, P., Langematz, U., Lin, R., Long, C., Mears, C., Miller, A., Nash, J., Seidel, D. J., Thompson, D. W. J., $\mathrm{Wu}, \mathrm{F}$., and Yoden, S.: An update of observed stratospheric temperature trends, J. Geophys. Res.-Atmos., 114, D02107, https://doi.org/10.1029/2008JD010421, 2009.

Seidel, D. J., Gillett, N. P., Lanzante, J. R., Shine, K. P., and Thorne, P. W.: Stratospheric temperature trends: our evolving understanding, Wires Clim. Change, 2, 592-616, https://doi.org/10.1002/wcc.125, 2011.

Sheese, P. E., Boone, C. D., and Walker, K. A.: Detecting physically unrealistic outliers in ACE-FTS atmospheric measurements, Atmos. Meas. Tech., 8, 741-750, https://doi.org/10.5194/amt-8741-2015, 2015.

Sheese, P. E., Walker, K. A., Boone, C. D., Bernath, P. F., Froidevaux, L., Funke, B., Raspollini, P., and von Clarmann, T.: ACE-FTS ozone, water vapour, nitrous oxide, nitric acid, and carbon monoxide profile comparisons with MIPAS and MLS, J. Quant. Spectrosc. Ra., 186, 63-80, https://doi.org/10.1016/j.jqsrt.2016.06.026, 2017.

Sioris, C. E., McLinden, C. A., Fioletov, V. E., Adams, C., Zawodny, J. M., Bourassa, A. E., Roth, C. Z., and Degenstein, D. A.: Trend and variability in ozone in the tropical lower stratosphere over 2.5 solar cycles observed by SAGE II and OSIRIS, Atmos. Chem. Phys., 14, 3479-3496, https://doi.org/10.5194/acp-14-3479-2014, 2014.

Sofieva, V. F., Tamminen, J., Haario, H., Kyrölä, E., and Lehtinen, M.: Ozone profile smoothness as a priori information in the inversion of limb measurements, Ann. Geophys., 22, 3411-3420, https://doi.org/10.5194/angeo-22-3411-2004, 2004.

Sofieva, V. F., Rahpoe, N., Tamminen, J., Kyrölä, E., Kalakoski, N., Weber, M., Rozanov, A., von Savigny, C., Laeng, A., von Clarmann, T., Stiller, G., Lossow, S., Degenstein, D., Bourassa, A., Adams, C., Roth, C., Lloyd, N., Bernath, P., Hargreaves, R. J., Urban, J., Murtagh, D., Hauchecorne, A., Dalaudier, F., van Roozendael, M., Kalb, N., and Zehner, C.: Harmonized dataset of ozone profiles from satellite limb and occultation measurements, Earth Syst. Sci. Data, 5, 349-363, https://doi.org/10.5194/essd5-349-2013, 2013.

Sofieva, V. F., Kalakoski, N., Päivärinta, S.-M., Tamminen, J., Laine, M., and Froidevaux, L.: On sampling uncertainty of satellite ozone profile measurements, Atmos. Meas. Tech., 7, 18911900, https://doi.org/10.5194/amt-7-1891-2014, 2014a.

Sofieva, V. F., Tamminen, J., Kyrölä, E., Laeng, A., von Clarmann, T., Dalaudier, F., Hauchecorne, A., Bertaux, J.-L., Barrot, G., Blanot, L., Fussen, D., and Vanhellemont, F.: Validation of GOMOS ozone precision estimates in the stratosphere, Atmos. Meas. Tech., 7, 2147-2158, https://doi.org/10.5194/amt-7-21472014, 2014b

Sofieva, V. F., Ialongo, I., Hakkarainen, J., Kyrölä, E., Tamminen, J., Laine, M., Hubert, D., Hauchecorne, A., Dalaudier, F. Bertaux, J.-L., Fussen, D., Blanot, L., Barrot, G., and Dehn, A.: Improved GOMOS/Envisat ozone retrievals in the upper troposphere and the lower stratosphere, Atmos. Meas. Tech., 10, 231 246, https://doi.org/10.5194/amt-10-231-2017, 2017.

SPARC: SPARC Report on the Lifetimes of Stratospheric OzoneDeleting Substances, Their Replacements, and Related Species, edited by: Ko, M. K. W., Newman, P. A., Reimann, S., Strahan, S. E., SPARC Report No. 6, WCRP-15/2013, available at: http:// www.sparc-climate.org/publications/sparc-reports/ (last access: 23 October 2017), 2013.

Steinbrecht, W., Froidevaux, L., Fuller, R., Wang, R., Anderson, J., Roth, C., Bourassa, A., Degenstein, D., Damadeo, R., Zawodny, J., Frith, S., McPeters, R., Bhartia, P., Wild, J., Long, C., Davis, S., Rosenlof, K., Sofieva, V., Walker, K., Rahpoe, N., Rozanov, A., Weber, M., Laeng, A., von Clarmann, T., Stiller, G., Kramarova, N., Godin-Beekmann, S., Leblanc, T., Querel, R., Swart, D., Boyd, I., Hocke, K., Kämpfer, N., Maillard Barras, E., Moreira, L., Nedoluha, G., Vigouroux, C., Blumenstock, T., Schneider, M., García, O., Jones, N., Mahieu, E., Smale, D., Kotkamp, M., Robinson, J., Petropavlovs kikh, I., Harris, N., Hassler, B., Hubert, D., and Tummon, F.: An update on ozone profile trends for the period 2000 to 2016, Atmos. Chem. Phys., 17, 1067510690, https://doi.org/10.5194/acp-17-10675-2017, 2017.

Tamminen, J., Kyrölä, E., Sofieva, V. F., Laine, M., Bertaux, J.L., Hauchecorne, A., Dalaudier, F., Fussen, D., Vanhellemont F., Fanton-d'Andon, O., Barrot, G., Mangin, A., Guirlet, M., Blanot, L., Fehr, T., Saavedra de Miguel, L., and Fraisse, R.: GOMOS data characterisation and error estimation, Atmos. Chem. Phys., 10, 9505-9519, https://doi.org/10.5194/acp-109505-2010, 2010.

Thompson, D. W. J., Seidel, D. J., Randel, W. J., Zou, C.-Z., Butler, A. H., Mears, C., Osso, A., Long, C., and Lin, R.: The mystery of recent stratospheric temperature trends, Nature, 491, 692697, https://doi.org/10.1038/nature11579, 2012.

Tikhonov, A.: On the solution of incorrectly stated problems and method of regularization, Dokl. Akad. Nauk. SSSR+, 151, 501504, 1963.

Toohey, M. and von Clarmann, T.: Climatologies from satellite measurements: the impact of orbital sampling on the standard error of the mean, Atmos. Meas. Tech., 6, 937-948, https://doi.org/10.5194/amt-6-937-2013, 2013.

Tukiainen, S., Kyrölä, E., Verronen, P. T., Fussen, D., Blanot, L., Barrot, G., Hauchecorne, A., and Lloyd, N.: Retrieval of ozone profiles from GOMOS limb scattered measurements, At- 
mos. Meas. Tech., 4, 659-667, https://doi.org/10.5194/amt-4659-2011, 2011.

Tukiainen, S., Kyrölä, E., Tamminen, J., Kujanpää, J., and Blanot, L.: GOMOS bright limb ozone data set, Atmos. Meas. Tech., 8, 3107-3115, https://doi.org/10.5194/amt-8-3107-2015, 2015.

Tummon, F., Hassler, B., Harris, N. R. P., Staehelin, J., Steinbrecht, W., Anderson, J., Bodeker, G. E., Bourassa, A., Davis, S. M., Degenstein, D., Frith, S. M., Froidevaux, L., Kyrölä, E., Laine, M., Long, C., Penckwitt, A. A., Sioris, C. E., Rosenlof, K. H., Roth, C., Wang, H.-J., and Wild, J.: Intercomparison of vertically resolved merged satellite ozone data sets: interannual variability and long-term trends, Atmos. Chem. Phys., 15, 3021-3043, https://doi.org/10.5194/acp-15-3021-2015, 2015.

von Clarmann, T., Glatthor, N., Grabowski, U., Höpfner, M., Kellmann, S., Kiefer, M., Linden, A., Tsidu, G. M., Milz, M., Steck, T., Stiller, G. P., Wang, D. Y., Fischer, H., Funke, B., Gil-López, S., López-Puertas, M., Mengistu Tsidu, G., Milz, M., Steck, T., Stiller, G. P., Wang, D. Y., Fischer, H., Funke, B., Gil-López, S., and López-Puertas, M.: Retrieval of temperature and tangent altitude pointing from limb emission spectra recorded from space by the Michelson Interferometer for Passive Atmospheric Sounding (MIPAS), J. Geophys. Res., 108, 4736, https://doi.org/10.1029/2003JD003602, 2003.

von Clarmann, T., Höpfner, M., Kellmann, S., Linden, A., Chauhan, S., Funke, B., Grabowski, U., Glatthor, N., Kiefer, M., Schieferdecker, T., Stiller, G. P., and Versick, S.: Retrieval of temperature, $\mathrm{H}_{2} \mathrm{O}, \mathrm{O}_{3}, \mathrm{HNO}_{3}, \mathrm{CH}_{4}, \mathrm{~N}_{2} \mathrm{O}, \mathrm{ClONO}_{2}$ and $\mathrm{ClO}$ from MIPAS reduced resolution nominal mode limb emission measurements, Atmos. Meas. Tech., 2, 159-175, https://doi.org/10.5194/amt-2159-2009, 2009.
Wang, H. J., Cunnold, D. M., Thomason, L. W., Zawodny, J. M., and Bodeker, G. E.: Assessment of SAGE version 6.1 ozone data quality, J. Geophys. Res.-Atmos., 107, 8-18, https://doi.org/10.1029/2002JD002418, 2002.

WMO: Scientific Assessment of Ozone Depletion: 2010, Geneva, Switzerland, 2011.

WMO: Scientific assessment of ozone depletion, Global Ozone Research and Monitoring Project-Report No. 52, Geneva, Switzerland, available at: https://www.esrl.noaa.gov/csd/assessments/ ozone/ (last access: 23 October 2017), 2014.

Zawada, D. J., Dueck, S. R., Rieger, L. A., Bourassa, A. E., Lloyd, N. D., and Degenstein, D. A.: High-resolution and Monte Carlo additions to the SASKTRAN radiative transfer model, Atmos. Meas. Tech., 8, 2609-2623, https://doi.org/10.5194/amt-8-26092015, 2015.

Zawada, D. J., Rieger, L. A., Bourassa, A. E., and Degenstein, D. A.: Tomographic retrievals of ozone with the OMPS Limb Profiler: algorithm description and preliminary results, Atmos. Meas. Tech. Discuss., https://doi.org/10.5194/amt-2017-236, in review, 2017. 